\title{
Sediment Influx and Its Drivers in Farmers' Managed Irrigation Schemes in Ethiopia
}

\author{
Zerihun Anbesa Gurmu 1,2,*, Henk Ritzema ${ }^{2}\left(\mathbb{D}\right.$, Charlotte de Fraiture $^{3}\left(\mathbb{D}\right.$, Michel Riksen $^{4}(\mathbb{D}$ \\ and Mekonen Ayana 5 (D) \\ 1 Faculty of Water Resources and Irrigation Engineering, Arba Minch University, P.O. Box 21, \\ Arba Minch 4400, Ethiopia \\ 2 Water Resources Management Group, Wageningen University, Droevendaalsesteeg 3a, \\ 6708 PB Wageningen, The Netherlands; henk.ritzema@wur.nl \\ 3 Department of Water Science and Engineering, IHE Delft Institute for Water Education, Westvest 7, \\ 2611 AX Delft, The Netherlands; c.defraiture@un-ihe.org \\ 4 Soil Physics and Land Management Group, Wageningen University, Droevendaalsesteeg 3a, \\ 6708 PB Wageningen, The Netherlands; michel.riksen@wur.nl \\ 5 Department of Water Resources Engineering, Adama Science and Technology University, P.O. Box 1888, \\ Adama 2118, Ethiopia; mekonen.ayana24@gmail.com \\ * Correspondence: zerihun.gurmu@wur.nl
}

check for updates

Citation: Gurmu, Z.A.; Ritzema, H.; Fraiture, C.d.; Riksen, M.; Ayana, M. Sediment Influx and Its Drivers in Farmers' Managed Irrigation Schemes in Ethiopia. Water 2021, 13, 1747. https://doi.org/10.3390/ w13131747

Academic Editor: Achim A. Beylich

Received: 30 April 2021

Accepted: 20 June 2021

Published: 24 June 2021

Publisher's Note: MDPI stays neutral with regard to jurisdictional claims in published maps and institutional affiliations.

Copyright: (c) 2021 by the authors. Licensee MDPI, Basel, Switzerland. This article is an open access article distributed under the terms and conditions of the Creative Commons Attribution (CC BY) license (https:/ / creativecommons.org/licenses/by/ $4.0 /)$.

\begin{abstract}
Excessive soil erosion hampers the functioning of many irrigation schemes throughout sub-Saharan Africa, increasing management difficulties and operation and maintenance costs. River water is often considered the main source of sedimentation, while overland sediment inflow is overlooked. From 2016 to 2018, participatory research was conducted to assess sediment influx in two irrigation schemes in Ethiopia. Sediment influx was simulated using the revised universal soil loss equation (RUSLE) and compared to the amount of sediment removed during desilting campaigns. The sediment deposition rate was $308 \mathrm{~m}^{3} / \mathrm{km}$ and $1087 \mathrm{~m}^{3} / \mathrm{km}$, respectively, for the Arata-Chufa and Ketar schemes. Spatial soil losses amounts to up to $18 \mathrm{t} / \mathrm{ha} / \mathrm{yr}$ for the Arata-Chufa scheme and $41 \mathrm{t} / \mathrm{ha} / \mathrm{yr}$ for the Ketar scheme. Overland sediment inflow contribution was significantly high in the Ketar scheme accounting for $77 \%$ of the deposited sediment, while only $4 \%$ of the sedimentation at the Arata-Chufa scheme came from overland flow. Feeder canal length and the absence of canal banks increased the sedimentation rate, however, this was overlooked by the stakeholders. We conclude that overland sediment inflow is an often neglected component of canal sedimentation, and this is a major cause of excessive sedimentation and management problems in numerous irrigation schemes in sub-Saharan Africa.
\end{abstract}

Keywords: irrigation; sediment; overland flow; soil loss

\section{Introduction}

Excessive sediment influx hampers the function of many water resource systems and irrigation infrastructures in sub-Saharan Africa, causing storage capacity reductions, opportunity costs and safety hazards [1-7]. The impact of excessive sedimentation is especially high in countries such as Ethiopia, where overland soil erosion is severe and limited resources are available to address the problem [8-10]. Soil erosion is a major factor limiting agriculture due to the loss of fertile topsoil. It has a prolonged effect on the agricultural sector as the rate of soil loss exceeds the soil formation rate [11].

Soil erosion also affects the overall performance of irrigation schemes. Due to excessive sedimentation, many irrigation schemes have been abandoned or operate far below full capacity [12,13]. In Ethiopia, most irrigation systems are the river diversion type. However, the country's rivers carry huge sediment loads, and therefore are a major source of sedimentation. Although soil erosion from the upland catchment is the ultimate source of sedimentation in many irrigation schemes, the specific source of sedimentation varies 
with the mechanism through which the sediment enters an irrigation scheme. An irrigation scheme can be threatened by sediment that comes from a river and an overland flow. River sediment enters an irrigation scheme via an intake structure. For example, Gurmu et al. [14] found that river sediment contributed more than $95 \%$ of the total sediment deposition in the studied irrigation schemes. Nonetheless, overland erosion flow can also contribute large quantities of sediment. The overland sediment inflow from onsite soil erosion of the catchment area after the intake structure (upland of the main canal) happens when the generated soil loss joins the canal after the intake structures. In some schemes, overland flow is the only source of sedimentation. The Bebeks irrigation scheme, for instance, is threatened only by overland sediment inflow [15]. The scheme is irrigated by entirely sediment-free spring water, nonetheless it performs far below capacity, mainly due to the sediment that entirely comes from an overland flow.

While many stakeholders recognize upstream erosion as a major driver of sedimentation in irrigation canals, most focus on erosion occurring upstream of the intake [16]. However, much of the overland sediment inflow emanates from the catchment upland of the main canal of the scheme itself. Moreover, deposition from overland flow is typically concentrated in the main canals, as secondary and tertiary canals tend to be built at higher elevations relative to field plots, with canals laid along the contour.

A lack of resources for operation and maintenance aggravates problems of excessive sedimentation [17], as the physical infrastructure of many schemes is deteriorated. In farmer-led schemes, farmers apply tacit knowledge to temporarily reduce the quantity of sediment entering their irrigation schemes, for example, by delaying water abstraction when river sediment loads are particularly heavy [16] and diverting surface runoff to prevent it from entering the canal (Figure 1). To clear excessive sedimentation, they organize seasonal or annual desilting campaigns, which are labor-intensive and require participation of many farmers over several days. For example, in one irrigation scheme serving 430 ha with a main canal length of $12 \mathrm{~km}$, some 3118 labor days were required per campaign to remove the accumulated sediment [16]. Of the total time required for crop cultivation, farmers were found to invest one-fourth of their time in sediment management activities [16]. However, even with this management, farmers have been unable to adequately and sustainably deal with problems of excessive sedimentation.

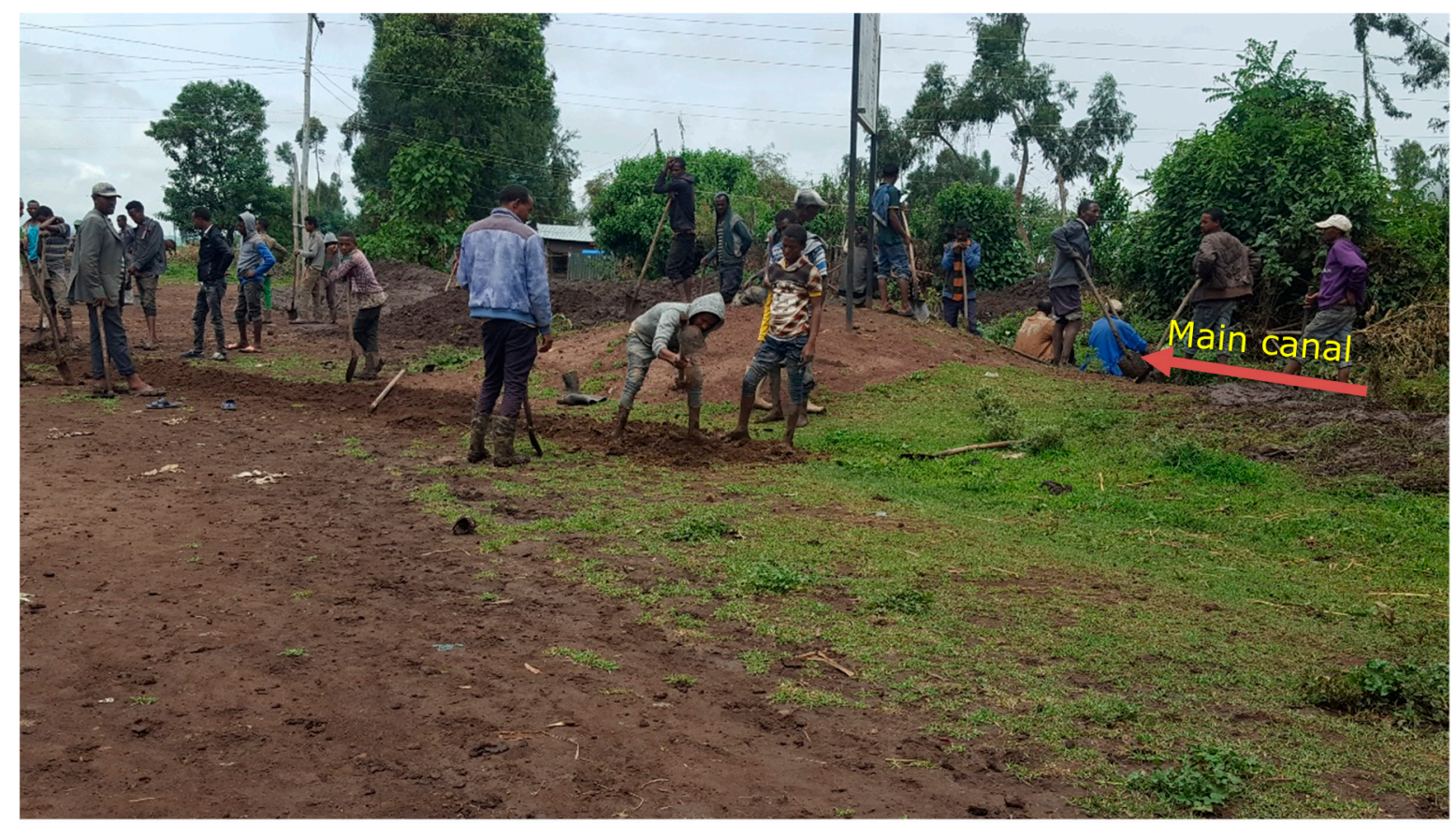

Figure 1. Farmers at the Ketar irrigation scheme diverting surface runoff to prevent sediment from entering the main canal, 25 August 2018. 
Sustainable sedimentation management requires identification of sedimentation sources and quantification of their respective contributions. Yet, most studies on sediment transport in irrigation schemes deal mainly with river sediment. Despite taking a greater share of overall sedimentation quantity in the irrigation schemes, little is known about the contribution of overland erosion flow to sedimentation problems. Therefore, in the current research we quantified soil loss and sediment yield and compared it with the sedimentation volume measured in two small-scale irrigation schemes in the Great Rift Valley Basin of Ethiopia—one of the River Basins in the country that exhibit severe soil losses.

\section{Materials and Methods}

\subsection{Location of the Study}

Two representative small-scale irrigation schemes, namely Arata-Chufa and Ketar from Ethiopia, were selected for the study. Both are gravity type river diversion schemes and both are affected by river and overland sediment inflow. Furthermore, both schemes are operated and maintained by farmers, and were in proper use at the time of the research. Farmers devote time and labor to keep the schemes in working order, despite problems of excessive sediment load and deposition. However, both schemes have differences in the sources and quantity of sedimentation, command area size, type and layout and management structure. Figure 2 presents the location of the two schemes in the Great Rift Valley Basin of Central Ethiopia, on the lower reach of the Ketar River, a few kilometers before it joins Lake Ziway. Geographically, Arata-Chufa is located at $7^{\circ} 59^{\prime} \mathrm{N}$ and $39^{\circ} 02^{\prime} \mathrm{E}$ with an average elevation of $1740 \mathrm{~m}$ above mean sea level. Ketar was located at $7^{\circ} 49^{\prime} \mathrm{N}$ and $39^{\circ} 02^{\prime} \mathrm{E}$ at a mean elevation of $2294 \mathrm{~m}$ above mean sea level. The Arata-Chufa scheme covers 100 ha and serves 324 beneficiaries. The Ketar scheme covers 430 ha and serves 1074 beneficiaries.

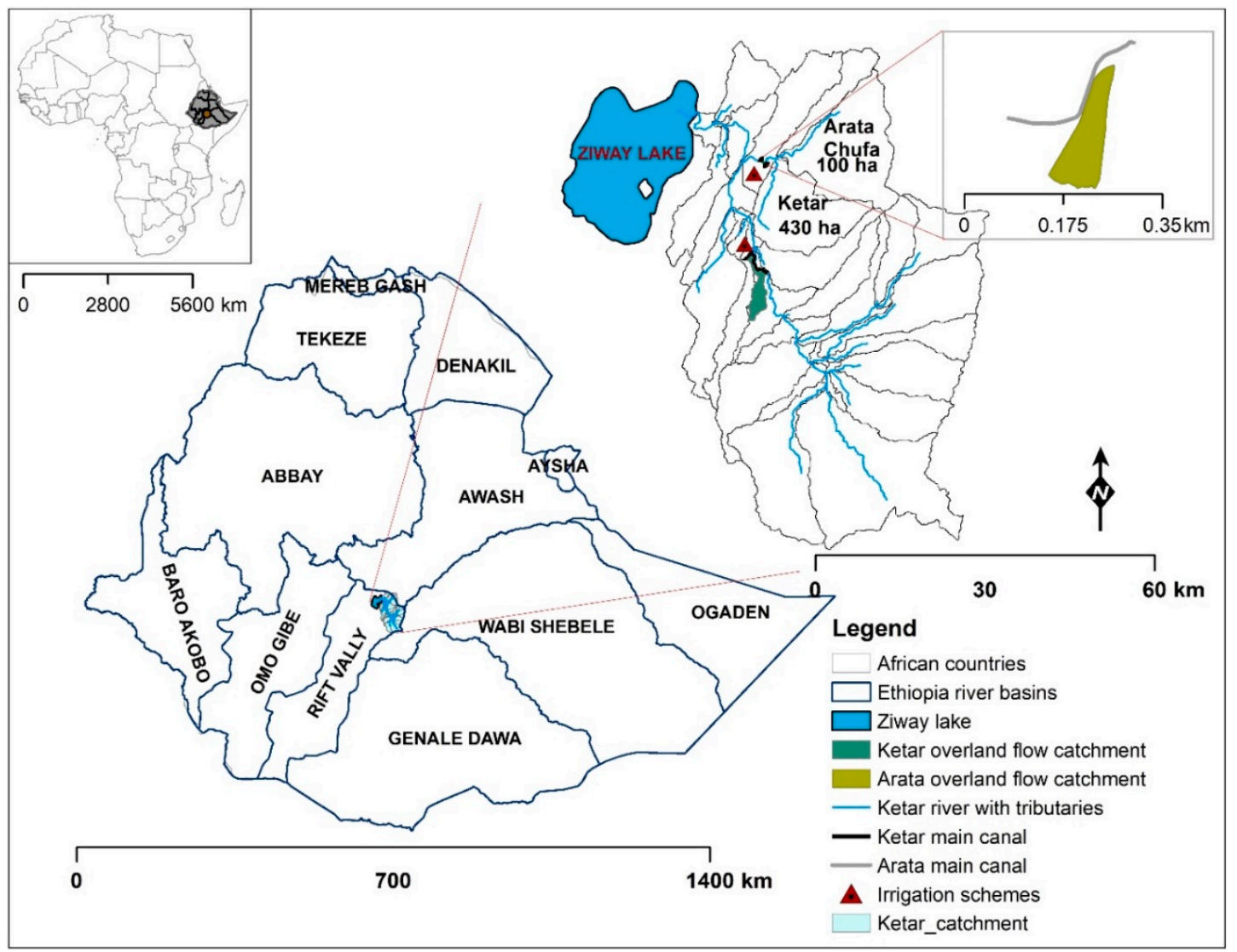

Figure 2. Location of the Arata-Chufa and Ketar irrigation schemes and the catchments contributing overland sediment inflow. 


\subsection{Field Data Collection}

Field data collection began with an inventory of the schemes, to get acquainted with the canal layout and to understand local conditions, sediment hotspots and canal desilting periods. Farmers reported that desilting campaigns took two to three weeks, with the work conducted only on two to three days in each of those weeks. Canal cleaning and repair activities were undertaken at the end of the rainy season, before the start of the new irrigation season. The summer (wet) season usually ceases in late August. Sediment cleaning activities started in the last week of August and were completed in early September. On average, sediment cleaning took 3 days at Arata-Chufa and 5.5 days at Ketar.

We measured the volume of sediment deposited in the canal and removed by the farmers in two years: 2017 and 2018. The volume of sediment removed in the year before the fieldwork, 2016, was estimated based on the flood marks on the sides of the canal with the participation of farmers. Most canal sections were lined with concrete, which meant that canal cross-sections were relatively uniform. For unlined canal sections, irregularities in canal depth, width and shape were considered in measuring and calculating sediment volumes. Canal transition and culvert sections were measured separately.

\subsection{Soil Erosion Modeling}

There are many empirical models for predicting soil losses and the corresponding sediment yields. However, their scope of application is limited, as they were developed using site-specific empirical data $[18,19]$. To deal with this shortcoming, numerical and physically based distributed models have been developed. These, however, require large amounts of input data for calibration and simulation [20] and show limited accuracy in data-scarce conditions [19]. Recent advancements in GIS and remote sensing have enabled empirical models to predict soil erosion cell by cell.

Since our study area is characterized by data scarcity, we modeled soil erosion using the revised universal soil loss equation (RUSLE) developed by Wishmeier and Smith [21] coupled with GIS and remote sensing. Due to its simplicity, RUSLE has been widely applied globally and proven to be of value in the Ethiopian highlands [19,22]. Figure 3 presents our conceptual framework, in which RUSLE was used to identify the main upland sediment sources and to quantify soil loss and sediment yield in the main canals of the schemes under investigation from overland flow sources.

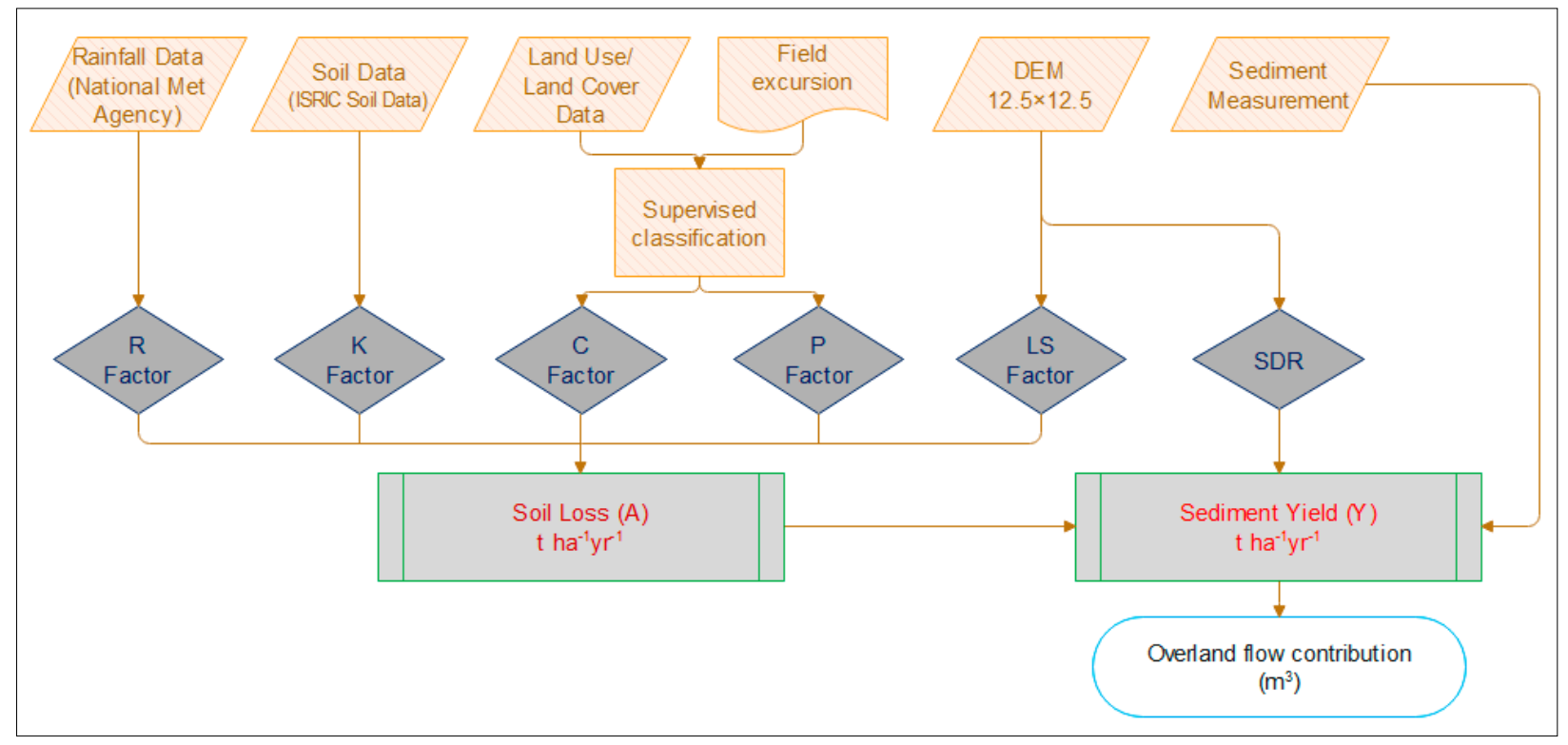

Figure 3. Conceptual framework for quantifying soil loss and sediment yield in the canals of the irrigation schemes from overland flow sources. 
Usually, the irrigation schemes are closed during the wet season (June to August) and irrigation is resumed after the farmers cleaned their scheme. During the wet season, the sediment enters the canal from the onsite soil erosion of the catchment area upland of the main canal. The volume of the sediment removed by the farmers incorporated both river and overland sediment inflow. We compared the sediment yield computed by RUSLE to the volume of sediment removed by farmers from the canals in their desilting campaigns to estimate the relative contribution of overland sediment inflow to total sediment deposition in the schemes. We conducted transect walks and participatory erosion mapping to identify erosion hotspots and major gully formations. Note that although the RUSLE model is limited in predicting gully erosion, major gully formations were absent in the study area.

Empirically RUSLE is expressed as follows:

$$
\mathrm{A}=\mathrm{R} \times \mathrm{K} \times \mathrm{LS} \times \mathrm{C} \times \mathrm{P}
$$

where

A is the mean annual soil loss (t/ha/yr),

$\mathrm{R}$ is the rainfall erosivity factor ( $\mathrm{MJ} \mathrm{mm} / \mathrm{ha} \mathrm{h} \mathrm{yr}$ ),

$\mathrm{K}$ is the soil erodibility factor ( $\mathrm{t}$ ha $\mathrm{h} / \mathrm{ha} \mathrm{MJ} \mathrm{mm}$ ),

LS is the slope length and steepness factor (dimensionless),

$\mathrm{C}$ is the land cover and management factor (dimensionless, ranges from zero to one),

$\mathrm{P}$ is the support practices factor (dimensionless, ranges from zero to one).

A $12.5 \mathrm{~m} \times 12.5 \mathrm{~m}$ digital elevation model (DEM) was used to delineate the catchment contributing overland sediment flow to the canals. First, a larger catchment was delineated taking outlet points in the river a bit downstream to the schemes. Then, many subcatchments were redelineated considering numerous outlet points in the main canal and the subcatchments were merged together. Using this method, the catchment contributing overland sediment flow to the Arata-Chufa scheme was delineated as 1.14 ha and it was delineated as 1082 ha for the Ketar scheme.

\subsubsection{Rainfall Erosivity}

Rainfall erosivity (the $\mathrm{R}$ factor) measures the ability of the impact of a raindrop to detach a soil particle. It is determined based on rainfall kinetic energy and 30-min rainfall intensity records. However, such rainfall measurements were hardly available for the study area. We thus estimated the R factor, following Hurni [23], based on the mean annual precipitation as follows:

$$
\mathrm{R}=0.562 \times \mathrm{P}-8.12
$$

where $P$ is the mean annual rainfall.

For the Arata-Chufa scheme, we used mean annual precipitation for 1987-2017 from Arata station records (Figure 4). For the Ketar scheme, nine meteorological stations were nearby. Rainfall interpolation mapping indicated that only the Ketar-Genet station was sufficiently representative of the rainfall characteristics of the catchment of interest. We therefore computed the rainfall erosivity factor using the mean annual precipitation data from the Ketar-Genet station for 1978-2014 (Figure 4). 


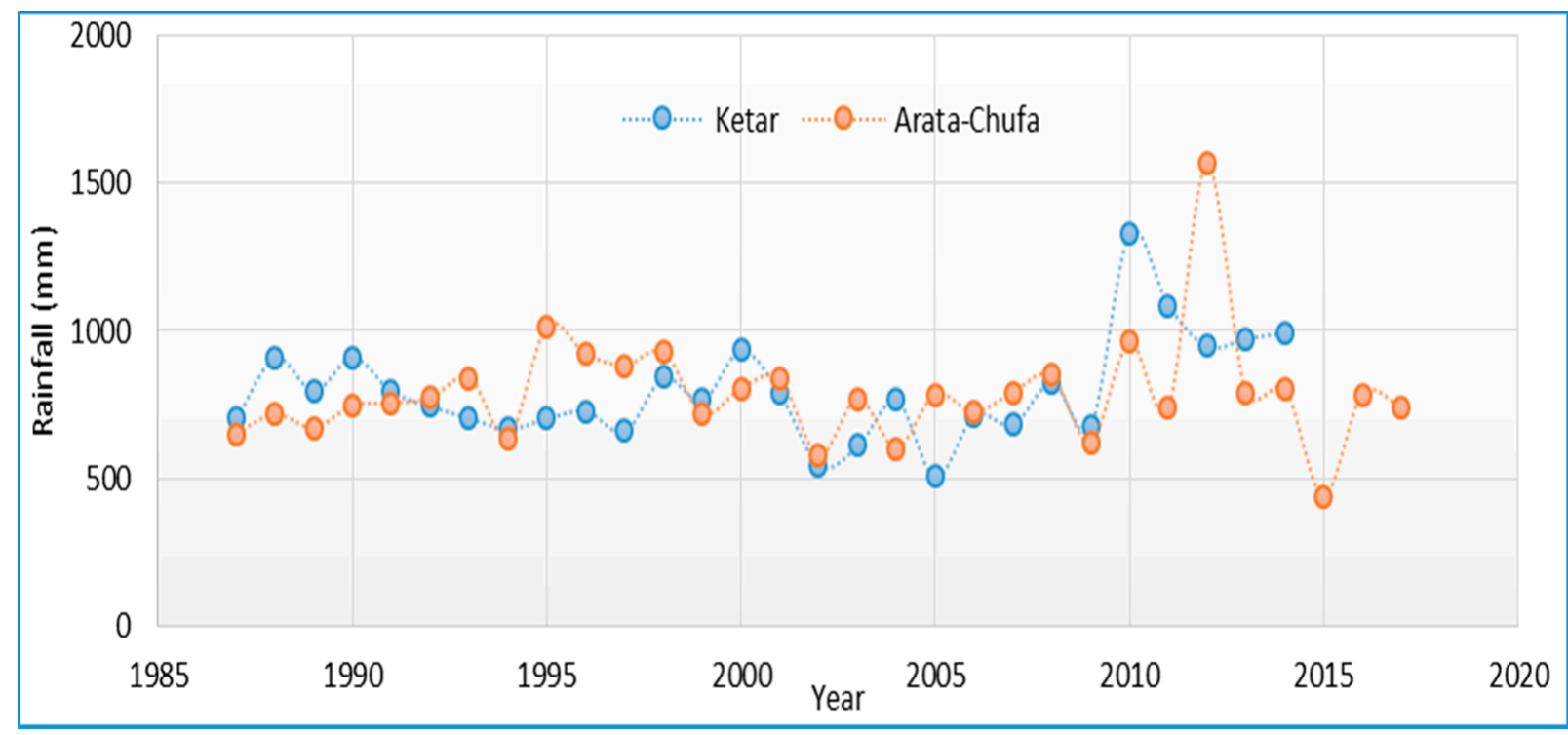

Figure 4. Mean annual rainfall for the Ketar-Genet station $\left(7^{\circ} 82^{\prime} \mathrm{N}\right.$ and $39^{\circ} 029^{\prime}$ E, altitude $\left.2314 \mathrm{~m}\right)$ and Arata station $\left(7^{\circ} 83^{\prime}\right.$ $\mathrm{N}$ and $39^{\circ} 1^{\prime} \mathrm{E}$, altitude $2400 \mathrm{~m}$ ).

\subsubsection{Soil Erodibility}

Soil erodibility (the $\mathrm{K}$ factor) represents the resistivity of soil particles to the impact of a raindrop. $\mathrm{K}$ is determined based on soil physical and chemical properties, such as the percentage of silt, clay and sand, organic carbon content and soil structure and permeability [19]. Data scarcity was again an obstacle in the study area. Previous authors [19,24] estimated $\mathrm{K}$ values based on observed soil color, as suggested by Hurni [23]. Williams [25] estimated $\mathrm{K}$ as a function of the percentage of silt, clay and sand and the organic carbon content of the topsoil. We explored different soil databases, including those of the Ethiopian Ministry of Water, Irrigation and Energy, the Ministry of Agriculture and Natural Resources and the Food and Agricultural Organization of the United Nations (FAO). Ultimately, we used data from the International Soil Reference and Information Centre (ISRIC), as it had better resolution $(1 \mathrm{~km} \times 1 \mathrm{~km})$ than the other sources. The following function was used to generate a $\mathrm{K}$ factor raster map for the catchments:

$$
\mathrm{K}=f_{\text {csand }} \times f_{\text {cl-si }} \times f_{\text {org }} \times f_{\text {hisand }}
$$

where

$f_{\text {csand }}$ is the function of coarse sand content,

$f_{c l-s i}$ is the function of the clay-to-silt ratio,

$f_{\text {org }}$ is the function of the organic carbon content,

$f_{\text {hisand }}$ is the function for high sand content.

Raster files for the above functions were processed in ArcGIS, using the data retrieved from the ISRIC soil database (Figure 5), as follows:

$$
\begin{gathered}
f_{\text {csand }}=\left[0.2+0.3 \times\left(-0.256 \times m_{s} \times\left(1-\frac{m_{\text {silt }}}{100}\right)\right]\right. \\
f_{\text {cl-si }}=\left[\frac{m_{\text {silt }}}{m_{c}+m_{\text {silt }}}\right]^{0.3} \\
f_{\text {org }}=\left[1-\frac{0.25 \times \text { orgC }}{\operatorname{org} C+\exp (3.72-2.95 \times \text { orgC })}\right]
\end{gathered}
$$




$$
f_{\text {hisand }}=\left[1-\frac{0.7 \times\left(1-\frac{m_{s}}{100}\right)}{\left(1-\frac{m_{s}}{100}\right)+\exp \left\langle-5.51+22.9 \times\left(1-\frac{m_{s}}{100}\right)\right\rangle}\right]
$$

where

$m_{S}$ is the sand content (\%),

$m_{\text {silt }}$ is the silt content $(\%)$,

$m_{c}$ is the clay content $(\%)$,

$\operatorname{org} C$ is the organic carbon content (\%).
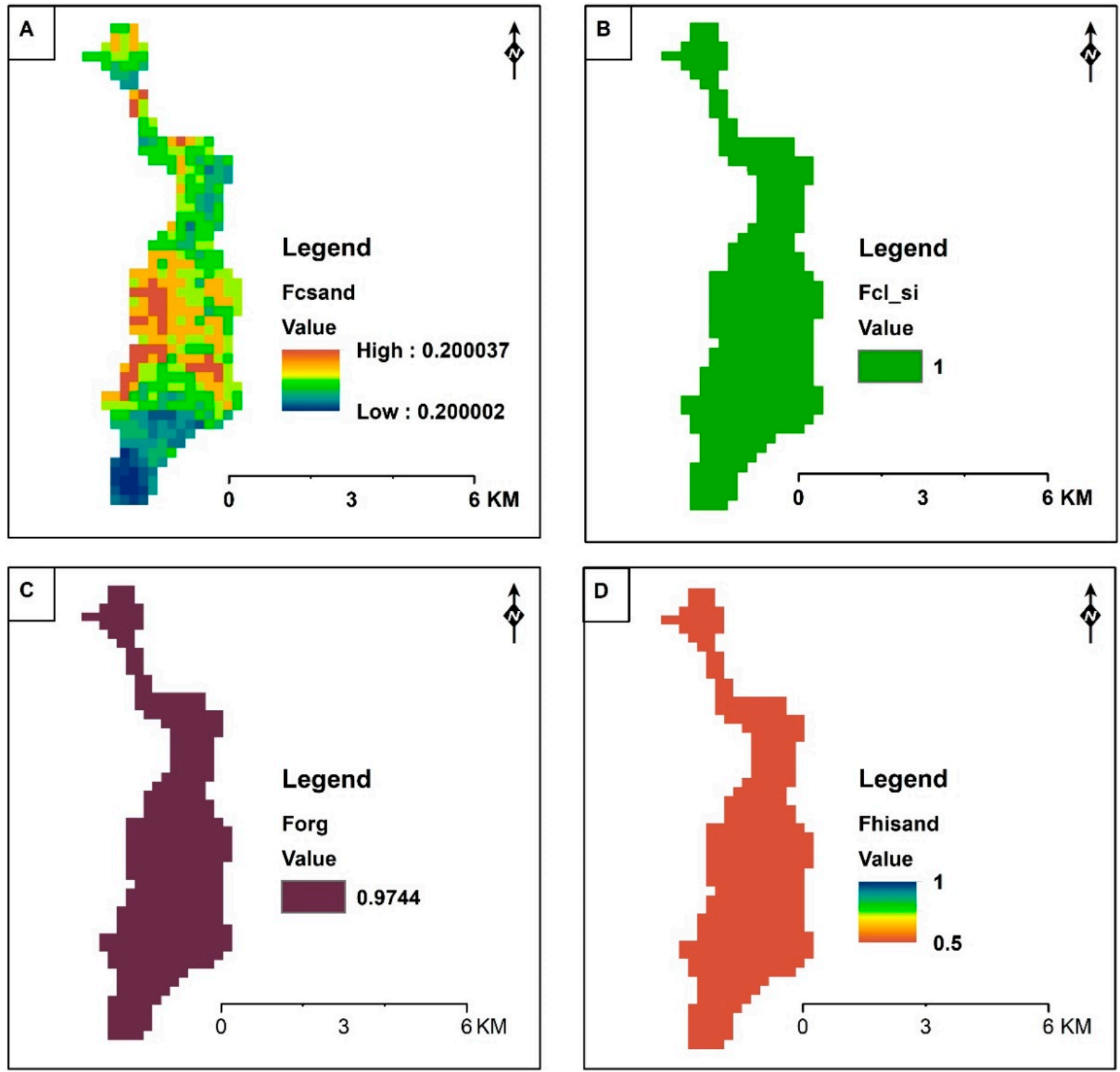

Figure 5. Physical and chemical properties of the soil in the study area. (A): Coarse sand content; (B): clay-to-silt ratio; (C): organic carbon content; (D): high sand content. Source: Data from the International Soil Reference and Information Centre (ISRIC). Available online at: https://data.isric.org/geonetwork/srv/eng/catalog.search\#/home (accessed on 3 October 2019). 


\subsubsection{Slope Length and Steepness}

Slope length and steepness (the LS factor) represents the rate of soil loss per unit area of land from a field of length $22.13 \mathrm{~m}$ and a uniform 9\% slope steepness [21]. LS is thus a topographic factor that reflects the sediment transport capacity of surface runoff [26]. The slope length (L) is the distance from the beginning of surface runoff to a point where either a change in slope occurs or the flow concentrates in depressions [21]. The approach initially introduced by Wischmeier and Smith [21] to estimate LS did not fully account for the effects of uphill slope and vegetation cover $[27,28]$. Compared to the other erosion parameters, estimation of LS is more controversial for catchments with complex topography $[27,28]$. This is because downhill erosion is determined not only by the erosive power of rainfall and the erodibility of a particular soil, but also by upslope flow accumulation due to uphill topography and land use types and vegetation cover [27-29].

To calculate slope length $(\mathrm{L})$ of a complex, three-dimensional terrain, many studies (e.g., $[19,24,26-28,30,31])$ adopt a grid-based approach based on the upslope contributing area. The current study used such an approach, as follows:

$$
\mathrm{LS}=\left(\frac{\mathrm{A}_{\mathrm{s}}}{22.13}\right)^{\mathrm{m}}\left(\frac{\sin \beta}{0.0896}\right)^{\mathrm{n}}
$$

where $A_{s}$ is the upslope contributing area and $\beta$ is the slope angle.

Equation (5) was used in a GIS environment to generate an LS factor map of the area contributing overland runoff flow to the main canals under study. For this purpose, a $12.5 \mathrm{~m} \times 12.5 \mathrm{~m}$ DEM was employed to derive the slope angle to compute the topographic factor.

$$
\text { LS }=\left(\text { Flow accumulation } \times \frac{\text { Cell size }}{22.13}\right)^{0.4} \times\left(\frac{\text { sin slope }}{0.0896}\right)^{1.3}
$$

\subsubsection{Land Cover and Management}

Land cover and management (the $C$ factor) considers the effect of land cover, soil biomass and farming practices on the rate of soil loss $[18,32]$. The $C$ factor is the ratio of soil loss with a specific surface cover to the corresponding soil loss from a bare fallow area [19-21]. For this study, we mapped the $C$ factor in conformance with land use and land cover maps obtained from the Ethiopian Ministry of Water, Irrigation and Energy and the Ministry of Agriculture and Natural Resources. As the temporal and spatial scale of these maps did not accurately represent real-time land use and land cover conditions in the study area, we minimized uncertainty in $C$ value determination $[33,34]$ with supplementation of land use and land cover data gathered during the fieldwork. The development of a $\mathrm{C}$ factor map was supported by supervised classification of locally collected land use data, following recommendations from different studies. For agricultural land use types, C values were derived based on the type of farming and slope of the area (Table 1). 
Table 1. Land cover and management ( $\mathrm{C}$ factor) and support practices (P factor) values used to compute soil loss with the revised universal soil loss equation (RUSLE).

\begin{tabular}{|c|c|c|c|c|c|}
\hline Land Use/Cover & Description & Slope $(\%)$ & C & $\mathbf{P}$ & References \\
\hline \multirow{5}{*}{ Cropland } & & $0-7$ & 0.17 & 0.65 & \\
\hline & Areas intensively cultivated to grain & $7-11.3$ & 0.20 & 0.70 & \\
\hline & crops with contour planting and no soil & $11.3-17.6$ & 0.30 & 0.75 & \\
\hline & and water conservation measures & $17.6-26.8$ & 0.34 & 0.80 & \\
\hline & & $>26.8$ & 0.4 & 0.90 & \\
\hline Bare soil & Land surface without vegetation cover & & 0.4 & 0.65 & \\
\hline Closed shrub & $\begin{array}{l}\text { Mixed shrub and grassland, with } \\
50-70 \% \text { of land area covered }\end{array}$ & & 0.1 & 0.8 & {$[19,21,32-36]$} \\
\hline Open shrub & $\begin{array}{l}\text { Mixed shrub and grassland, with fair to } \\
\text { good cover }\end{array}$ & & 0.12 & 0.75 & \\
\hline Open grassland & $\begin{array}{c}\text { Fair to good grass cover (closed } \\
\text { grazing) }\end{array}$ & & 0.15 & 0.7 & \\
\hline Sparse forest & $\begin{array}{l}\text { Open forest with grassland, with fair to } \\
\text { good cover }\end{array}$ & & 0.03 & 0.85 & \\
\hline
\end{tabular}

\subsubsection{Support Practices}

Support practices (the $\mathrm{P}$ factor) represents the effect of specific land management practices in reducing runoff and resultant soil losses compared to a situation without those practices with upslope or downslope cultivation $[19,21]$. The $P$ factor accounts for the effect of structural and non-structural erosion control measures on soil loss. Taye et al. [34] established $p$ values for agricultural and range lands with various soil and water conservation measures in Northern Ethiopia. For the current study in Central Ethiopia, we determined $p$ values based on recommendations from the literature (Table 1).

\subsection{Sediment Yield}

The volume of sediment that ended up in the cross-section of the main canals was computed as a function of the gross soil loss from the catchment contributing surface runoff and the sediment delivery ratio (SDR). Haregeweyn et al. [37], Nyssen et al. [35] and Williams and Berndt [38] developed SDR as a function of catchment physiography, sediment particle size, runoff rate and land use or cover types. The attempt to develop SDR for Ethiopian highlands by Haregeweyn et al. [37] was reportedly unsuccessful. Jain et al. [39] computed SDR based on the relationship between suspended sediment and discharge. In a similar study, Haregeweyn et al. [19], following Nyssen et al. [35], computed SDR based on land use types with or without soil and water conservation practices and they used a SDR of $30 \%$ for agricultural land and $25 \%$ for non-agricultural land. Bhattarai and Dutta [40] derived SDR from overland flow travel time, which is dependent on the terrain and land cover characteristics.

We used the approach suggested by Williams and Berndt [38], computing the SDR for the study area as follows:

$$
\mathrm{SDR}=0.627 \times \mathrm{SLP}^{0.403}
$$

where SLP is the slope of the main stream channel (\%).

This method has been found to yield reasonable estimates of sediment yield in datascarce regions [20,41]. As for many empirical equations, this method may not result in an accurate estimate of SDR. Nonetheless, due to limited data availability in the study area, using another option of SDR would still result in the same uncertainty. To minimize the uncertainty, we compared the estimated SDR value computed using this approach with the findings of other studies reported in the country.

We computed the RUSLE factors for the two irrigation schemes under study and used Map Algebra in ArcGIS to quantify the corresponding soil loss and sediment yield. Various statistical analyses were performed to classify the catchment based on soil erosion rates. 


\section{Results}

\subsection{Raster Maps of RUSLE Factors}

Raster maps depicting the RUSLE parameters were created for each scheme, ArataChufa (Figure 6) and Ketar (Figure 7). These maps show the spatial distribution of rainfall erosivity (Figures $6 \mathrm{~A}$ and $7 \mathrm{~A}$ ), soil erodibility (Figures $6 \mathrm{~B}$ and $7 \mathrm{~B}$ ), topography (Figures 6C and 7C), land cover and management (Figures 6D and 7D) and support practices (Figures $6 \mathrm{E}$ and $7 \mathrm{E}$ ). Figures $6 \mathrm{~F}$ and $7 \mathrm{~F}$ present the land cover map of the catchment used to develop the RUSLE parameters for the Arata-Chufa and the Ketar schemes, respectively.
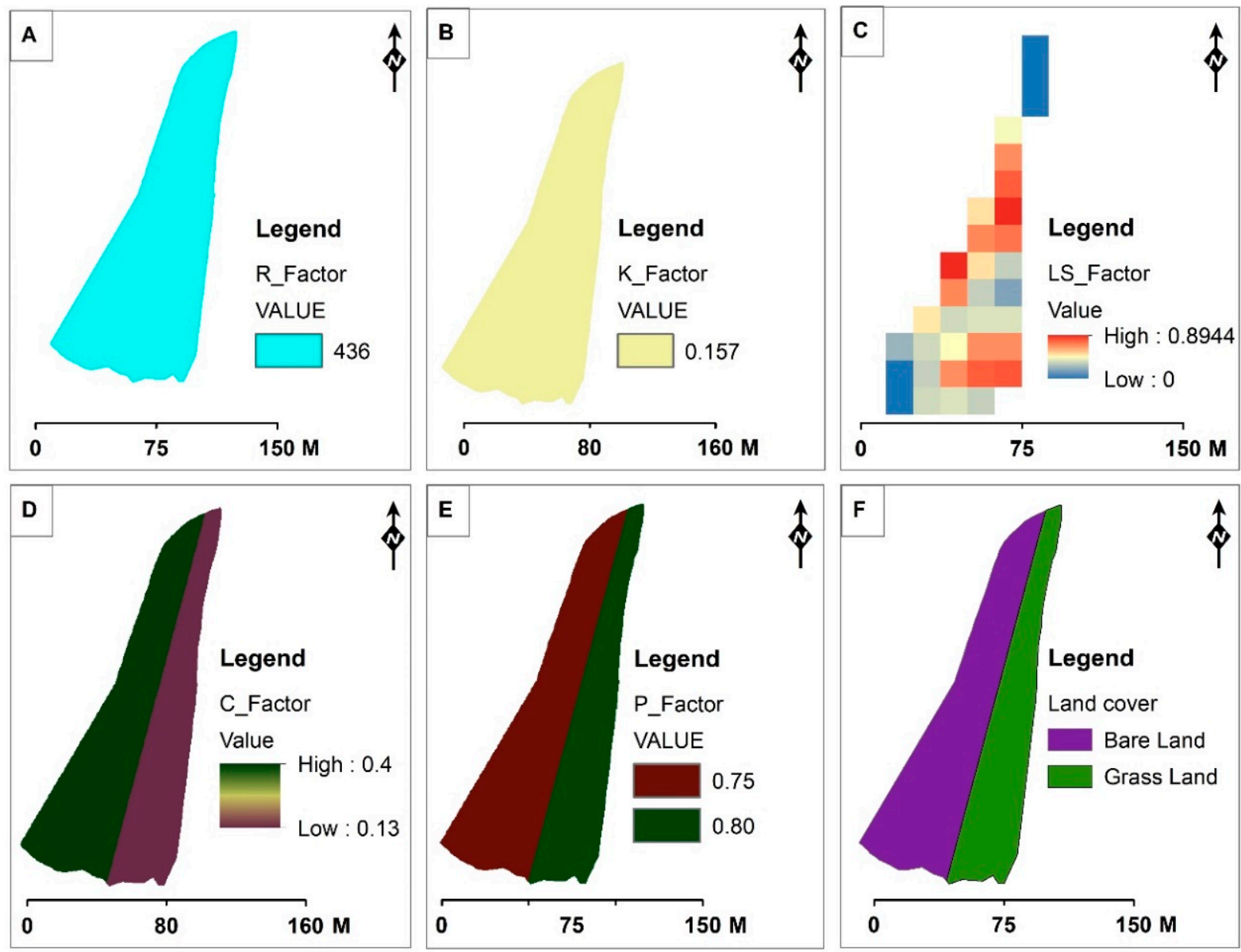

Figure 6. Raster maps of catchment contributing overland sediment inflow to the main canal of the Arata-Chufa scheme. (A-E) depict factors of the revised universal soil loss equation. (A): Mean annual soil loss (R factor); (B): soil erodibility (K factor); (C): slope length and steepness (LS factor); (D): land cover and management (C factor); (E): support practices (P factor). (F): Maps land cover in the study area.

$\mathrm{R}$ is uniform for the whole catchment as the mean annual precipitation from a single station used to estimate the rainfall erosivity factor. Note that the catchments were quite small, which limits spatial rainfall variability.

Pellic vertisols were the dominant soil types in the study area. These have a soil erodibility ( $\mathrm{K}$ factor) of about 0.15 for black cotton soil, estimated from the easily identifiable soil color [22]. Using the ISRIC soil database, we estimated the K factor as 0.157 for ArataChufa and as 0.195 for Ketar. These values were largely in line with the estimated values based on soil color. 

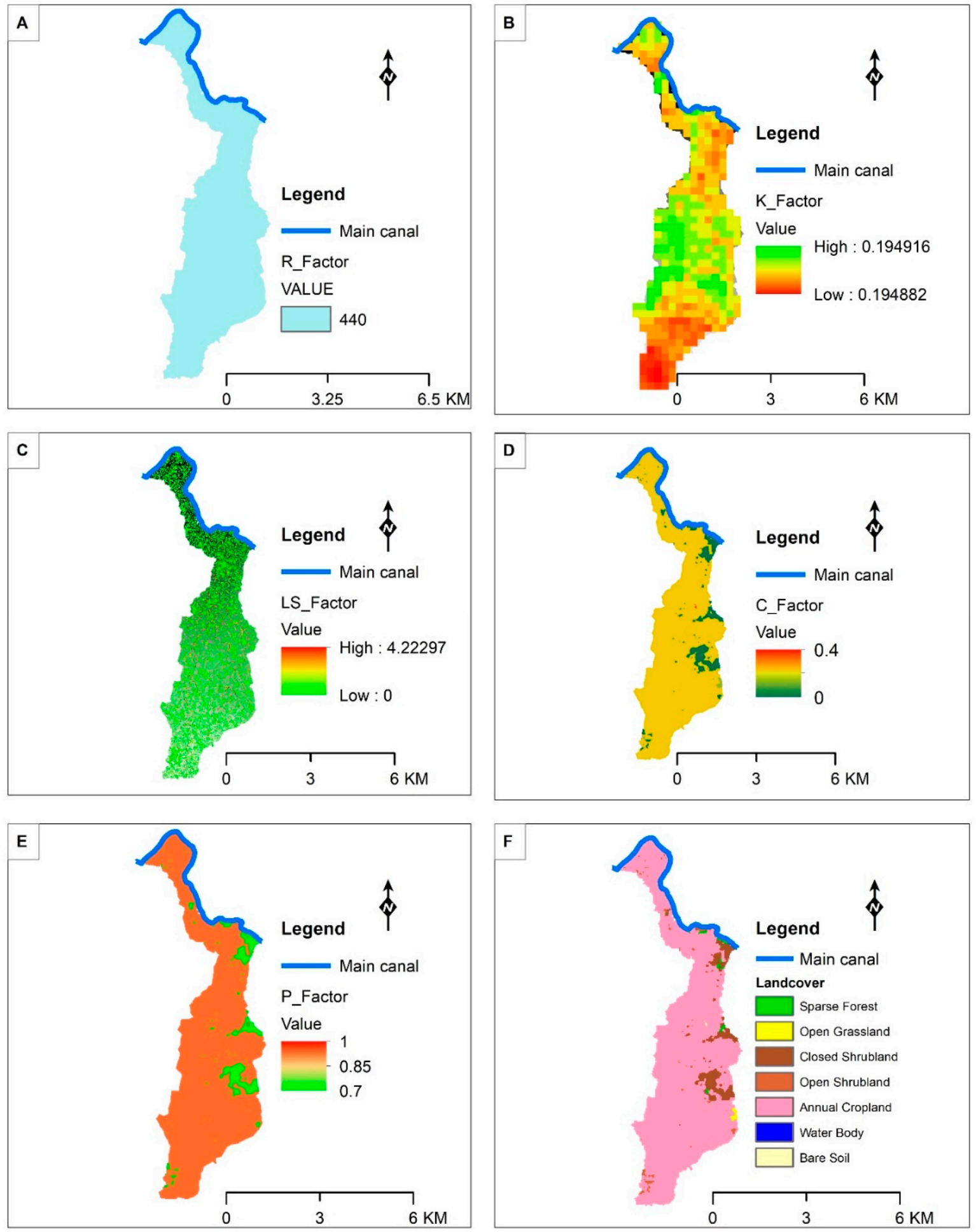

Figure 7. Raster maps of catchment contributing overland sediment inflow to the main canal of the Ketar scheme. (A-E) depict factors of the revised universal soil loss equation. (A): Mean annual soil loss (R factor); (B): soil erodibility (K factor); (C): slope length and steepness (LS factor); (D): land cover and management (C factor); (E): support practices (P factor). (F): Maps land cover in the study area.

The complexity of the terrain affects the computation of the LS factor or slope length and steepness. The Arata-Chufa catchment exhibited moderate topographic variability, with elevations ranging from 1725 to $1730 \mathrm{~m}$ above mean sea level. The elevation gradient of the Ketar catchment was larger, with elevations ranging from $2258 \mathrm{~m}$ above mean sea 
level close to the main canal to $2488 \mathrm{~m}$ above mean sea level at the upstream escarpment of the catchment.

At the Arata-Chufa scheme, sedimentation from surface runoff came mainly from a gravel road that crossed the main canal and an open area of grazing land between the main canal and this gravel road. At the Ketar scheme, various land cover and land use types contributed to the overland sediment flow. Particularly, a rainfed cropland upland of the main canal was the origin of most of the sediment, though there were also mixed grasslands, shrub and open forest in the catchment, with bare areas in between. These characteristics were considered in determining the $C$ factor for the study area. $C$ values ranged from 0.13 to 0.40 for Arata-Chufa and from 0 to 0.4 for Ketar.

No large-scale interventions have been implemented to reduce soil erosion. However, farmers use contour farming and a few have constructed soil bunds at the boundaries of their field plots, particularly at the Ketar irrigation scheme. Moreover, farmers leave biomass on the land after harvesting until the following plowing season. All of these practices help to reduce soil erosion and thus were considered in determining the $\mathrm{P}$ factor for the catchments. P values ranged from 0.75 to 0.80 for the Arata-Chufa scheme and from 0.65 to 1.00 for the Ketar scheme.

\subsection{Estimation of Soil Loss Rate}

The pixel-by-pixel estimate of soil loss rates for the catchment of the Arata-Chufa scheme varies from $18 \mathrm{t} / \mathrm{ha} / \mathrm{yr}$ for bare land (the gravel road) in the upstream part of the catchment to zero for the largely grass-covered zone in the lower catchment, close to the main canal (Figure 8A). Mean annual soil loss for the catchment was estimated at $8.9 \mathrm{t} / \mathrm{ha} / \mathrm{yr}$, whereas the mean annual sediment yield to the Arata-Chufa main canal from the corresponding catchment was $2.32 \mathrm{t} / \mathrm{ha} / \mathrm{yr}$. Sediment yields varied across the catchment, ranging from zero to $4.3 \mathrm{t} / \mathrm{ha} / \mathrm{yr}$ (Figure $8 \mathrm{~B}$ ).
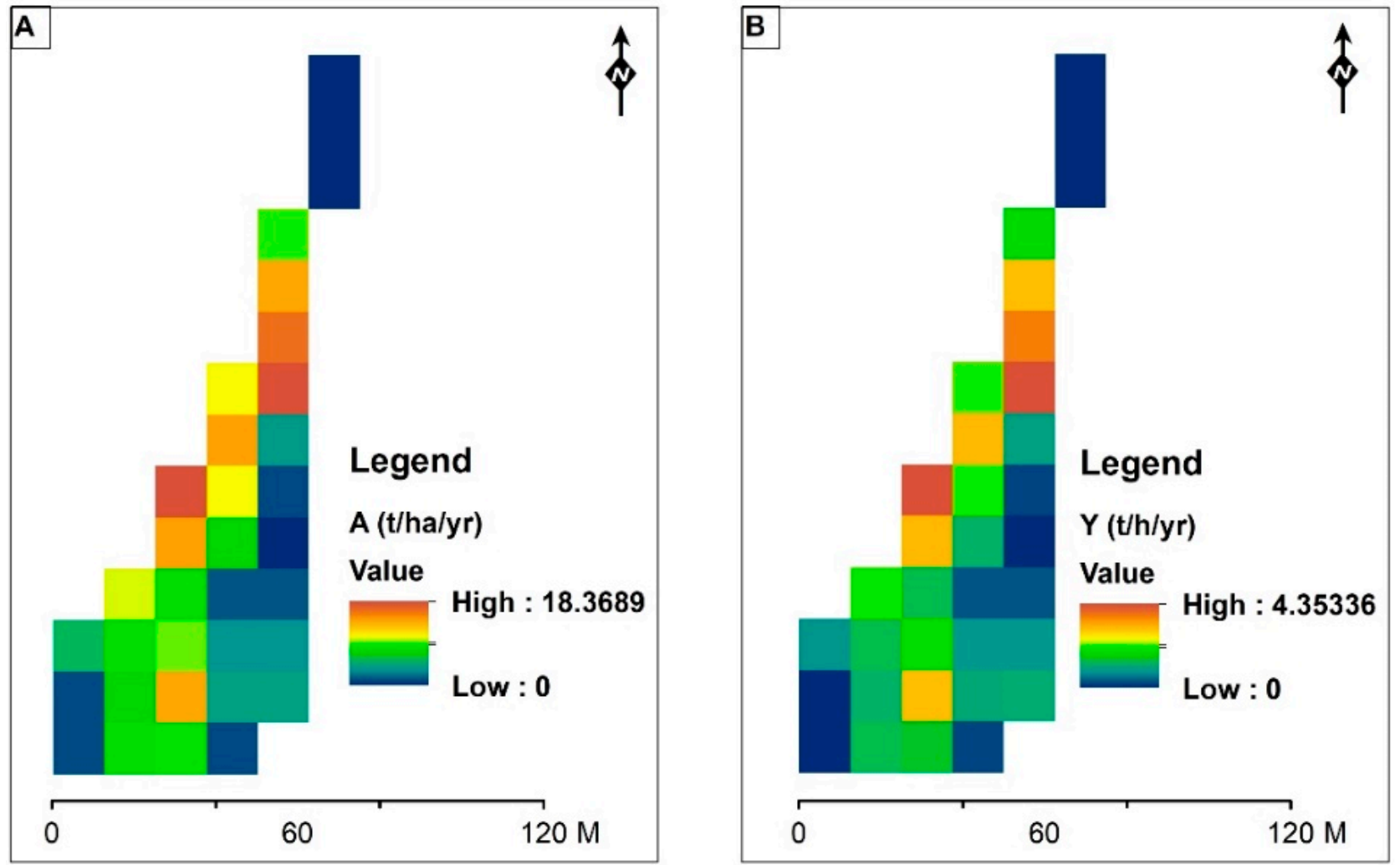

Figure 8. Annual soil loss (A) and sediment yield (B) in the catchment contributing overland sediment inflow to the main canal of the Arata-Chufa irrigation scheme. 
The grid-based soil loss modeling for the catchment at the Ketar scheme shows annual soil losses ranging from 0 , in the lower reach of the catchment, to $41 \mathrm{t} / \mathrm{ha} / \mathrm{yr}$ (Figure $9 \mathrm{~A}$ ). Particularly high soil loss rates were registered along the steep, narrow drainage channels extending upland from the main canal. Mean annual soil loss of the catchment was estimated at $18.5 \mathrm{t} / \mathrm{ha} / \mathrm{yr}$, whereas sediment yield to the catchment contributing sediment to the Ketar main canal ranged from 0 to $6.2 \mathrm{t} / \mathrm{ha} / \mathrm{yr}$ (Figure 9B).

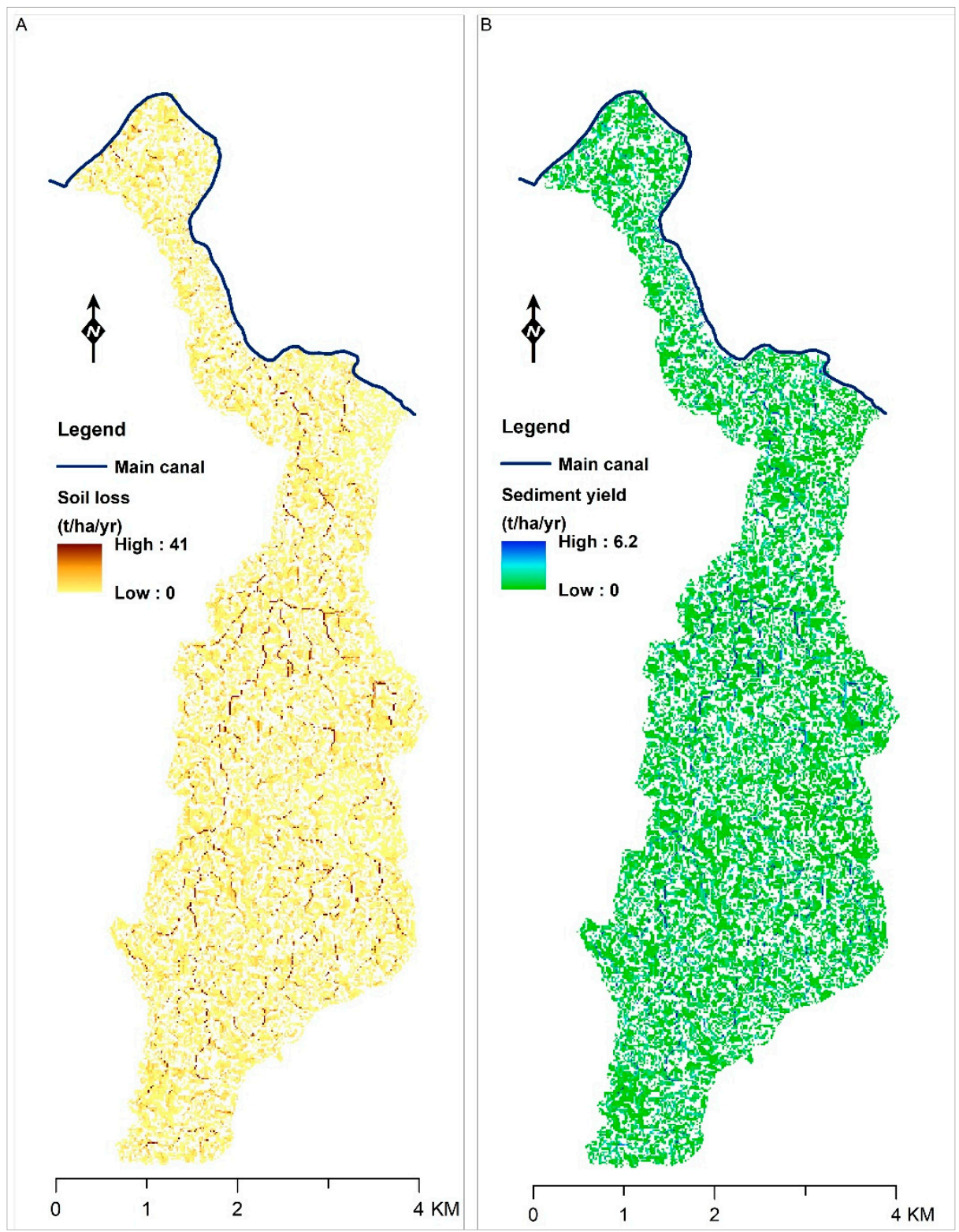

Figure 9. Annual soil loss (A) and sediment yield (B) in the catchment contributing overland sediment inflow to the main canal of the Ketar irrigation scheme.

\subsection{Field Measurement of Sedimentation in the Schemes}

Sedimentation, both river sediment and overland sediment inflow, in the main canals of the schemes was measured at the end of the wet season. At the Arata-Chufa scheme, sedimentation averaged $181 \mathrm{~m}^{3} / \mathrm{yr}$. To remove this volume of sediment, some 256 farmers worked $4.5 \mathrm{~h}$ a day for 5.5 days, together removing $0.22 \mathrm{~m}^{3}$ of sediment per day (Figure 10, Figure A1, Table A1). 

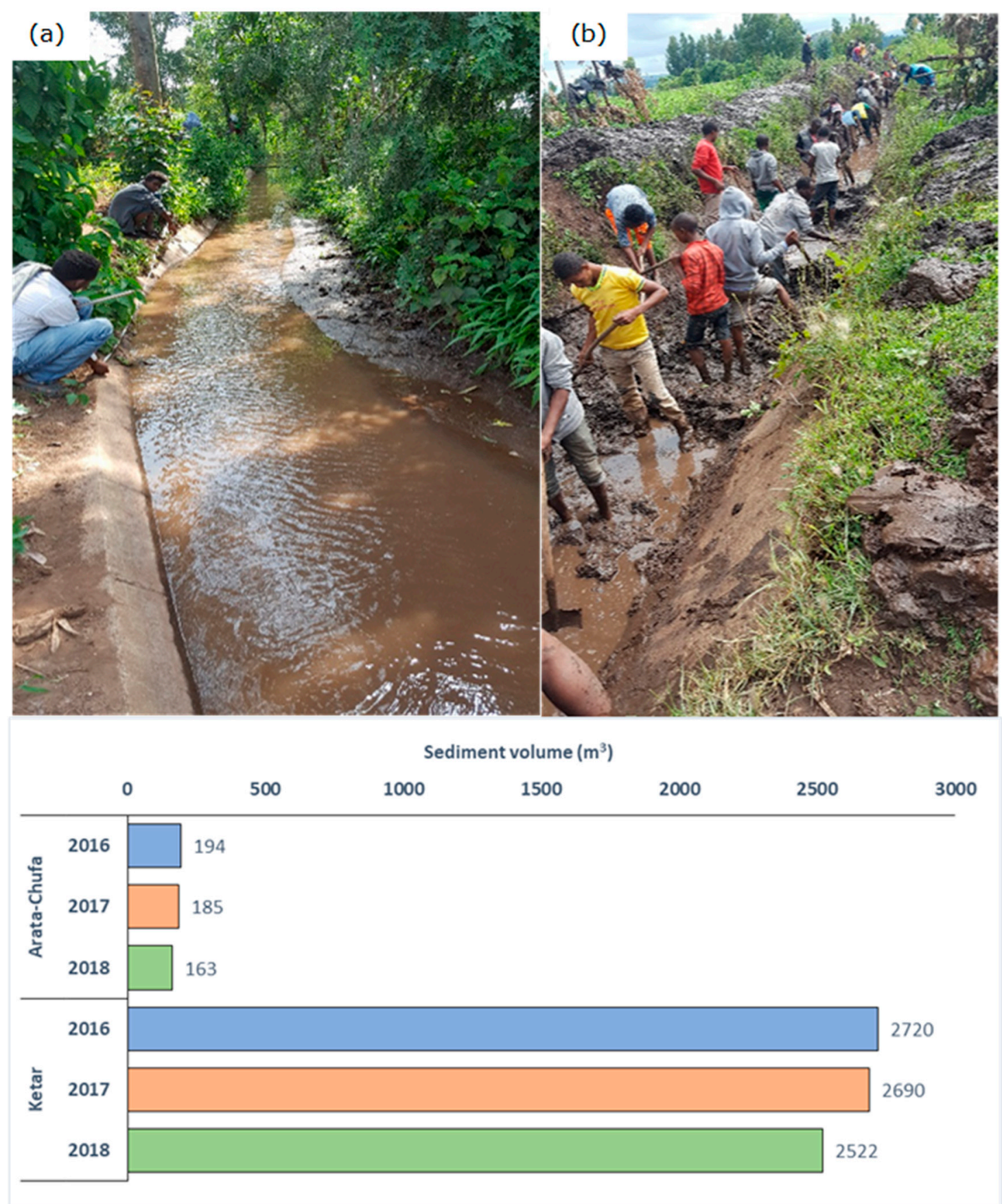

Figure 10. Volume of sediment removed from the main canal of the (a) Arata-Chufa and (b) Ketar irrigation scheme.

At Ketar, much of the sediment was deposited over only $20 \%$ of the main canal $(2433 \mathrm{~m})$. This critical section was $4.5 \mathrm{~km}$ from the intake and had a milder longitudinal bed slope $(0.130 \%$ o $)$ compared to the other sections of the main canal. On average, $2644 \mathrm{~m}^{3}$ of sediment per year was removed from this section of the main canal (see Figure 10). Totally 3118 farmers participated in the desilting campaigns, together removing $0.83 \mathrm{~m}^{3}$ of sediment over three 5-h working days (Figure 10, Figure A1, Table A1).

Comparison of the volumes of sediment measured in 2017 and 2018 to the sediment volumes estimated for the year prior to the fieldwork (2016) indicate a decrease in sediment volumes from 2016 to 2018, by $10.3 \%$ and $4.2 \%$, respectively, for the Arata-Chufa and Ketar schemes. There is a strong correlation between the sediment volume in 2016 and the mean 
of the sediment volumes in 2017 and 2018, with the correlation being 0.76 for Arata-Chufa and 0.83 for Ketar (Figure 11).

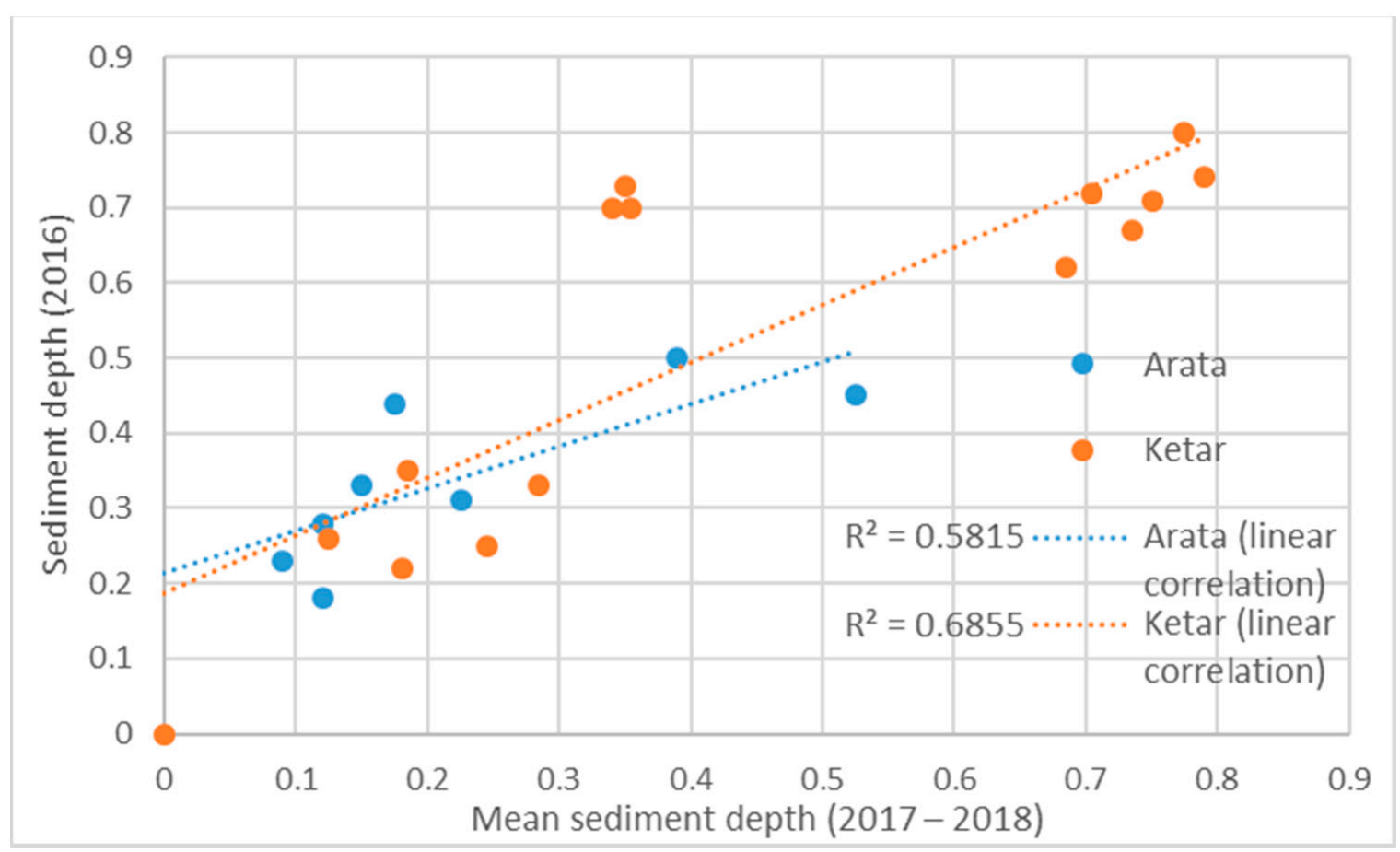

Figure 11. Correlation between the mean of the sediment volumes in 2017 and 2018 and the sediment volume estimated for 2016 using flood and sediment marks with farmer participation.

\subsection{Overland Sediment Inflow Contribution}

Overland flow sediment inflow concerns the part of the sediment that comes from the erosion of the catchment area upland of the main canal after the diversion structure and does not enter the scheme via regular intake structures. The onsite overland flow sediment enters the schemes along the main canal lateral. The contribution of overland sediment inflow is estimated by comparing the sediment yield modeled using RUSLE with the gross sediment volume removed from the schemes. The irrigation season runs from September to May (dry season) after dredging the deposited sediment that comes from river and overland flow. During the fieldwork at Arata-Chufa, we observed sediment inflow from surface runoff, despite the small size of the sediment-contributing catchment. Our erosion models indicate that the gross soil loss from this catchment was $10 \mathrm{t} / \mathrm{yr}$. The corresponding sediment yield to the Arata-Chufa main canal was estimated as $2.6 \mathrm{t} / \mathrm{yr}$ (Table 2).

Table 2. Annual soil loss, sediment yield to contributing catchment and quantity of sediment dredged from the main canal of the Arata-Chufa and Ketar schemes.

\begin{tabular}{ccccc}
\hline & Soil Loss (A) & \multicolumn{2}{c}{ Sediment Yield (Y) } & \multicolumn{2}{c}{ Measured Dredged Sediment } \\
\hline Rate & Gross & Rate & Gross & Gross (2016-2018) \\
\hline$\left(\mathbf{m}^{3} / \mathbf{h a} / \mathbf{y r}\right)$ & $\left(\mathbf{m}^{3} / \mathbf{y r}\right)$ & $\left(\mathbf{m}^{3} / \mathbf{h a} / \mathbf{y r}\right)$ & $\left(\mathbf{m}^{3} / \mathbf{y r}\right)$ & $\left(\mathbf{m}^{3} / \mathbf{y r}\right)$ \\
25.2 & 28.7 & Arata-Chufa irrigation scheme & 7.52 & 181 \\
52.4 & 56,697 & 6.6 & 2042 & 2644 \\
\hline
\end{tabular}


The Ketar scheme experienced higher soil loss from the catchment and correspondingly large sediment inflow to the main canal. Gross annual soil loss was estimated as $20,017 \mathrm{t}$, and the corresponding sediment yield to the main canal of the scheme was estimated as $720 \mathrm{t}$, with a mean annual sediment yield of $3.44 \mathrm{t} /$ ha (see Table 2).

The Arata-Chufa scheme was affected mainly by sediment delivered by the river water feeding the scheme. Most erosion surface flow was conveyed into the river by a channel along the gravel road, which crossed the main canal (Figure 12). Measurement of sediment volumes in the main canal and soil erosion modeling indicate that surface runoff contributed about $4.3 \%\left(7.5 \mathrm{~m}^{3}\right)$ of the total volume of sediment deposited in the main canal.
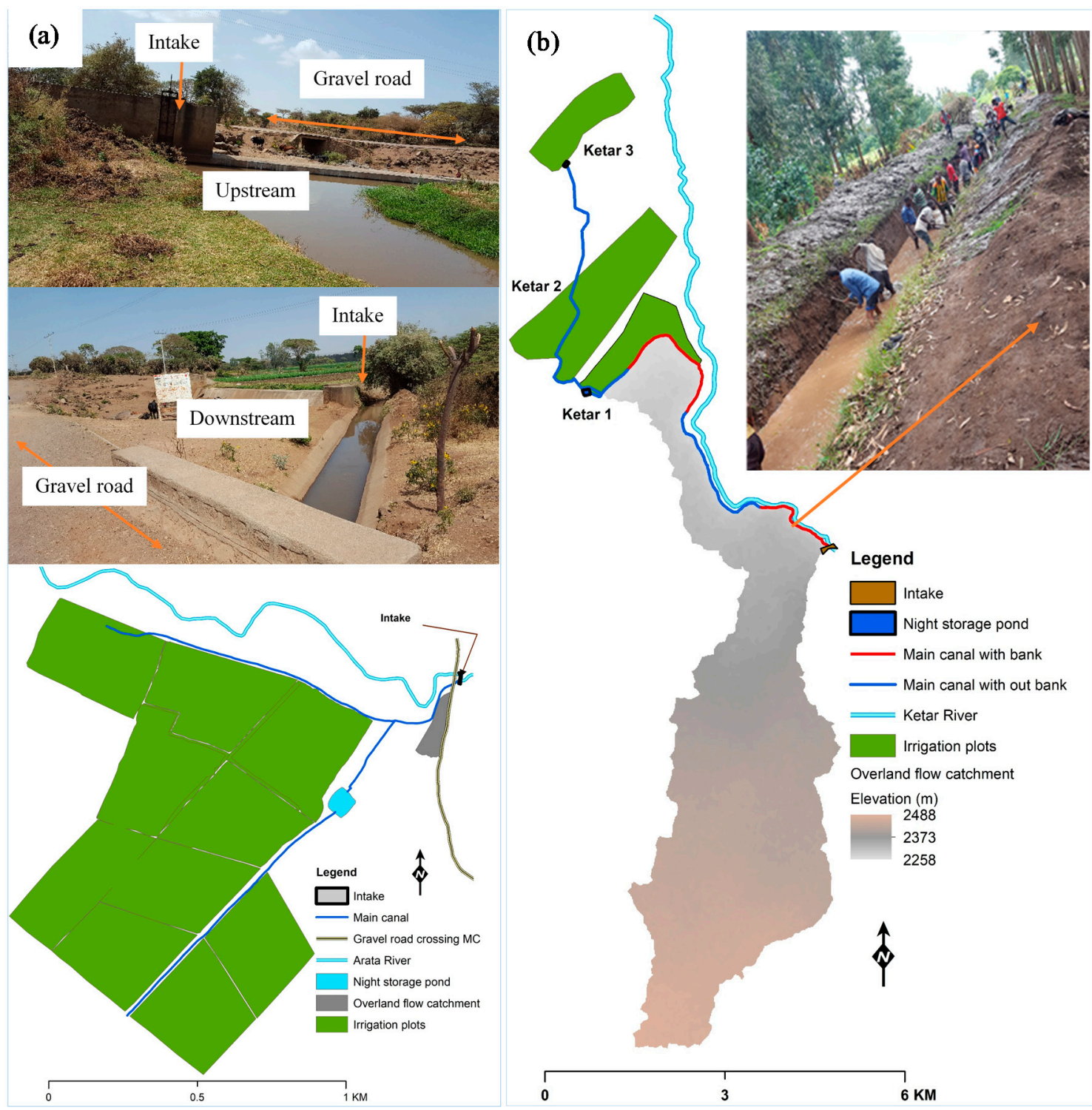

Figure 12. Layout of irrigation schemes and overland sediment flow in contributing catchment: (a) Arata-Chufa and (b) Ketar. At Ketar, the main canal segments labeled 'with bank' have a ridge embankment that helps protect the canal against overland sediment inflow.

The Ketar scheme main canal travelled some $4.5 \mathrm{~km}$ as a headrace canal from the intake to the field plots through various land use types, though mostly croplands (see Figure 12). Moreover, there was a lack of land conservation activities and the main canal was highly deteriorated due to years of use and a lack of maintenance. These factors contributed 
to overland sedimentation inflow to the main canal. Another factor, however, was the ridges, which had been formed alongside the main canal from sediment removed over years of desilting campaigns. These ridges played an important role in reducing sediment inflow to the canal. Nonetheless, sediment yield analyses show a large contribution of overland sediment inflow to the total volume of sediment deposited in the Ketar main canal. Specifically, overland flows accounted for some $77 \%\left(2042 \mathrm{~m}^{3}\right)$ of the gross volume of sediment deposited in the Ketar main canal.

The Arata-Chufa scheme had a shorter feeder canal. Here, the contribution of overland sediment flow into the main canal was found to be minimal (Table 3). Notwithstanding this, the main canal of the scheme became fully silted-up at the end of the cropping season, that is, within a three to four months period. For such a scheme, therefore, overland sediment will likely not be a priority concern. For the Ketar irrigation scheme, however, the volume of overland sediment inflow per unit of main canal was high $\left(167 \mathrm{~m}^{3} / \mathrm{km}\right)$ (Table 3). Explanations for this high overland sediment inflow include the long length of the main canal from intake to the first irrigation plot $(4.5 \mathrm{~km})$ and a lack of protection of the main canal from overland sediment inflow.

Table 3. Overland sediment inflow to the schemes per unit of irrigable land, per length of main canal and per user.

\begin{tabular}{|c|c|c|}
\hline Per unit of Irrigable Land & Per Length of Main Canal & Per User \\
\hline$\left(\mathrm{m}^{3} / \mathrm{ha}\right)$ & $\left(\mathrm{m}^{3} / \mathrm{km}\right)$ & $\left(\mathrm{m}^{3} /\right.$ farmer $)$ \\
\hline \multicolumn{3}{|c|}{ Arata-Chufa irrigation scheme } \\
\hline 0.08 & 5.76 & 0.02 \\
\hline \multicolumn{3}{|c|}{ Ketar irrigation scheme } \\
\hline 4.74 & 167.05 & 1.90 \\
\hline
\end{tabular}

\subsection{Soil Loss Severity Analysis}

While sedimentation of the Arata-Chufa scheme was found to be due primarily to the entry of sediment-laden river water, with the contribution of overland sediment flow relatively low, it is noteworthy that $92 \%$ of overland sediment inflow to the Arata-Chufa main canal came from the gravel road that crossed the main canal (Table 4, Figure 12).

Table 4. Severity classes of soil erosion loss for the area contributing sediment to the main canal of the Arata-Chufa and Ketar irrigation schemes. The severity classes are adapted from [19].

\begin{tabular}{|c|c|c|c|c|c|c|}
\hline $\begin{array}{c}\text { Erosion Severity } \\
\text { Classes }\end{array}$ & $\begin{array}{l}\text { Range of Soil } \\
\text { Loss }\end{array}$ & Area & $\begin{array}{l}\text { Percentage of } \\
\text { Total Area }\end{array}$ & $\begin{array}{l}\text { Mean Annual } \\
\text { Soil Loss }\end{array}$ & $\begin{array}{l}\text { Total Annual } \\
\text { Soil Loss }\end{array}$ & $\begin{array}{l}\text { Percentage of } \\
\text { Total Soil Loss }\end{array}$ \\
\hline & (t/ha/yr) & (ha) & $(\%)$ & (t/ha/yr) & (t/ha/yr) & $\%$ \\
\hline \multicolumn{7}{|c|}{ Arata-Chufa irrigation scheme } \\
\hline Very slight & $0-5$ & 0.29 & 25.44 & 3.12 & 0.90 & 8.42 \\
\hline Slight & $5-15$ & 0.75 & 65.79 & 10.78 & 8.09 & 75.21 \\
\hline Moderate & $15-30$ & 0.1 & 8.77 & 17.60 & 1.76 & 16.37 \\
\hline Severe & $30-50$ & - & - & - & - & - \\
\hline Very severe & $>50$ & - & - & - & - & - \\
\hline Total & & 1.14 & & & 10.75 & \\
\hline \multicolumn{7}{|c|}{ Ketar irrigation scheme } \\
\hline Very slight & $0-5$ & 1067.70 & 98.65 & 0.4 & 17055.00 & 70.58 \\
\hline Slight & $5-15$ & 10.93 & 1.01 & 9.2 & 3931.00 & 16.27 \\
\hline Moderate & $15-30$ & 3.53 & 0.33 & 21.3 & 2952.00 & 12.22 \\
\hline Severe & $30-50$ & 0.15 & 0.01 & 37.8 & 227.00 & 0.94 \\
\hline Very severe & $>50$ & - & - & - & - & - \\
\hline Total & & 1082 & & & 24,165 & \\
\hline
\end{tabular}


At the Ketar scheme, our soil erosion risk analysis indicates that $12 \%$ and $1 \%$ of sediment deposition in the main canal originated, respectively, from lands classified as 'moderately' and 'severely' at risk from soil erosion (Table 4). These classes are considered top priority when implementing structural and non-structural soil and water conservation measures. However, the total area of the catchment experiencing moderate to severe erosion rates was quite small compared to the entire catchment size. Indeed, the area exhibiting the highest erosion rates accounted for only about $0.4 \%$ of the total catchment area. Thus, to sustainably reduce excessive sedimentation, soil and water conservation activities should be implemented addressing the entire catchment.

\subsection{Uncertainity in the RUSLE Model}

Due to nonlinear spatiotemporal variability of parameters, the RUSLE model is sensitive to input variable uncertainties and the modeling results should be verified using local measurement data [42]. In particular, the model is highly sensitive to the LS factor (slope length and steepness) [43-45]. Moreover, the model cannot predict gully erosion. We used local data to minimize uncertainty in the input parameters and therefore in the model outcomes. Absence of gullies and an overall less complex catchment points to a general reliability of the sediment yield predictions for the Arata-Chufa scheme. At the Ketar scheme, land dynamics were more complex. Nonetheless, considering river sediment and total sediment inflows, the sediment yield volumes estimated by the RUSLE model were in a reasonable range.

\section{Discussion}

The annual soil losses estimated in this study are reasonably close to those reported by other authors from studies in the country. However, our mean annual soil loss estimate $(18.5 \mathrm{t} / \mathrm{ha} / \mathrm{yr})$ is lower than the national-level estimate of $29.9 \mathrm{t} / \mathrm{ha} / \mathrm{yr}$ by Haregeweyn et al. [46] and figures reported for North and North-Western Ethiopia, that is, $27.5 \mathrm{t} / \mathrm{ha} / \mathrm{yr}$ [19], $47.4 \mathrm{t} / \mathrm{ha} / \mathrm{yr}$ [24], $42.67 \mathrm{t} / \mathrm{ha} / \mathrm{yr}$ [47], $84 \mathrm{t} / \mathrm{ha} / \mathrm{yr}$ [48], 30.6 t/ha/yr [49] and $37 \mathrm{t} / \mathrm{ha} / \mathrm{yr}$ [50]. In a nationwide study, Sonneveld et al. [51] reported that mean annual soil losses varied from 0 in the east and south to greater than $100 \mathrm{t} / \mathrm{ha} / \mathrm{yr}$ in the northern and north-western escarpment. Kebede et al. [52] conducted a study in the Cheleleka watershed of the Central Rift Valley Basin of Ethiopia, where the current study area was also located. They reported annual soil losses in the range of $2.5-86 \mathrm{t} / \mathrm{ha}$. The current study's mean annual soil loss estimate $(18.5 \mathrm{t} / \mathrm{ha} / \mathrm{yr})$ is within this range and close to the $18.2 \mathrm{t} / \mathrm{ha} / \mathrm{yr}$ estimated by Hui et al. [53].

There is high uncertainty associated with the values estimated using the revised universal soil loss equation (RUSLE) model. To reduce the associated uncertainties, we verified the RUSLE input parameters against the data collected during fieldwork. For instance, the absence or presence of soil and water conservation activities, types of crop, length of the growing period, post-harvest activities, soil type, land use type and absence or presence of gullies were carefully analyzed while determining the RUSLE input parameters. The empirical equation (Equation (10)), used to estimate the sediment delivery ratio (SDR), is also subjected to uncertainty. The estimated value of SDR was $26 \%$ for the Arata-Chufa and $18 \%$ for the Ketar scheme. The estimated SDR values by the current study are close to $30 \%$ for agricultural land and 25\% for non-agricultural land estimated by Nyssen et al. [35] as used by Haregeweyn et al. [37]. One reason why our estimated mean annual soil loss is lower than the values reported by other authors for North and North-Western Ethiopia, could be the complexity of the terrain. As noted, topographic complexity plays a substantial role in the estimation of LS, which is a highly sensitive RUSLE parameter [54]. The current study area had moderate topographic complexity, while North and North-Western Ethiopia are well known for their rugged terrain and steep mountains.

Nearly $80 \%$ and $26 \%$ of the catchments at the Arata-Chufa and Ketar schemes, respectively, exhibited soil loss rates greater than the tolerable limits of $7.2 \mathrm{t} / \mathrm{ha} / \mathrm{yr}$ [55] and $10 \mathrm{t} / \mathrm{ha} / \mathrm{yr}$ [22]. Determination of appropriate tolerable limits is further dependent 
on local conditions, soil depth, rate of soil formation, terrain and rainfall characteristics. Findings from the current study indicate a need to implement conservation measures before it is too late and degradation becomes irreversible. In most places in the study area, soil was being lost at a rate faster than soil formation, which ranges from 2 to $22 \mathrm{t} / \mathrm{ha} / \mathrm{yr}$ in Ethiopia [56]. Soil losses greater than $10 \mathrm{t} / \mathrm{ha} / \mathrm{yr}$ are irreversible within a time span of 50-100 years [57]. Land degradation and a lack of conservation measures, particularly on croplands, contributed to high sedimentation rates in the study area. Soil loss in the study area had multiple effects. Among others, it caused deterioration of irrigation infrastructure and soil fertility loss. Many water conveyance and distribution structures had become dysfunctional due to excessive sedimentation and therefore could not deliver the required services. Water shortages, especially late in the irrigation season, were a major problem due to diminished canal capacities, leakages and malfunctioning water distribution structures. Excessive sedimentation also placed a heavy work burden on farmers, to keep the schemes operational. Reduced agricultural productivity due to a loss of nutrients in topsoil was another undesirable effect of soil erosion faced by farmers in the study area. Irrigated fields tended to be farmed under rainfed conditions during the wet season, which also led to an increased risk of soil loss.

The main determinant of the volume of overland sediment inflow appeared to be the layout of the irrigation scheme and upland land cover and land use. From the participatory mapping and transect walk during the fieldwork, we observed that the main canal of the Arata-Chufa scheme was mostly protected against potential overland sediment inflow. Moreover, the main canal extended only some $400 \mathrm{~m}$ before it reached the field plots. This short trajectory was of paramount importance in reducing sediment deposition from overland flow. Moreover, sedimentation from surface runoff came from a limited area, particularly, the gravel road that crossed the main canal downstream of the intake and the open area of grazing land between the main canal and the gravel road. The risk of overland sediment inflow at Ketar was substantially higher, as the canal traversed some $4.5 \mathrm{~km}$ from the intake to the field plots, through various land uses and land covers. Most of the sediment deposited into the main canal of this scheme originated from the rainfed croplands upland from the main canal.

We computed overland sediment yield into the canals by systematically delineating and classifying the catchments into subcatchments. This included subcatchments where banks protected the main canal against surface runoff and subcatchments without such canal banks, with the latter being more vulnerable to overland sediment flow into the main canal. Across the entire Ketar catchment, which covers 1082 ha, only 215 ha was found to directly contribute overland sediment flow to the Ketar main canal $(12.1 \mathrm{~km})$. Furthermore, over more than 30 years of desilting campaigns, Ketar farmers had dumped the sediment removed from the canal alongside the canal, forming a ridge that served to protect some parts of it from overland sediment inflow. However, this sediment ridge had grown to such a height that further sediment dredging activities were nearly impossible. Thus, the farmers were planning to organize a campaign to excavate the sediment accumulated on the banks, to make canal cleaning easier. Considering that with the protection of these and naturally occurring ridges, overland sediment flow still contributed nearly $77 \%$ of the total sediment deposited in the main canal, it is recommended that such excavation be done in tandem with construction of canal banks to prevent surface runoff inflow. This would help farmers sustainably address sedimentation problems, and save labor that would otherwise need to be invested in desilting campaigns.

Data scarcity is often a challenge in understanding processes of sedimentation in irrigation schemes and in designing sustainable measures to address excessive sedimentation. Annual sediment deposition in irrigation canals varies depending on many factors, including rainfall intensity and conservation measures to reduce soil loss. The sediment volumes measured in the current study correlated well with the volumes of sediment estimated with the participation of farmers based on flood and sediment marks on the walls of the canals. This is an important finding, as resource limitations often challenge 
collection of real-time data. Our correlation analysis reveals that a participatory approach can provide a source of reasonable data for conservation measures to deal with problems of excessive sedimentation.

\section{Conclusions}

We measured sedimentation volumes in two irrigation schemes in the Great Rift Valley Basin of Ethiopia in two successive years, 2017 and 2018, and estimated volumes for the year prior to the fieldwork, 2016, based on flood and sediment marks with farmers' support. Sediment inflow to the irrigation scheme main canals from overland flow was modelled using RUSLE. Erosion risk maps were prepared to predict the possible implementation of soil and water conservation measures to reduce soil losses. At Arata-Chufa, $4.3 \%$ of sedimentation in the canal was found to come from overland flow, while in Ketar this rate was $77 \%$.

Our soil erosion severity map indicates low to moderate erosion rates in most of the areas under study. Some $84 \%$ of the Arata-Chufa catchment and $87 \%$ of the Ketar catchment, respectively, demonstrated slight to very slight soil erosion. Areas that exhibited a severe risk of erosion were found along surface drainage channels. Prioritizing soil and water conservation measures in the areas with severe erosion risk would not significantly reduce sediment inflow into the canals, as these covered only a small part of the catchment. Addressing the whole catchment when implementing conservation measures or protecting the main canal from surface runoff by constructing canal banks would be of greater help in significantly and sustainably reducing sedimentation, particularly in the Ketar main canal. Land degradation and a lack of soil conservation measures worsened soil erosion in this study area. In the Ketar scheme, excessive sediment inflow with surface runoff was aggravated by deterioration of the canal, the absence of canal banks and the long distance between the intake and field plots. As a result, water availability diminished as the irrigation season progressed. Moreover, water conveyance and distribution structures became damaged and operation and maintenance costs increased.

Farmers were found to be generally unaware of the source of sedimentation in their schemes. Identifying these sources and quantifying their contributions provides a crucial starting point for sustainably addressing sedimentation problems. In the Ketar scheme, the overland sediment inflow was found to be huge. This points to the importance of considering overland sediment inflows when rehabilitating irrigation schemes or designing new schemes, to attain optimum conveyance of water and sediment.

Based on these results, three key recommendations are proposed. First, as sources of sedimentation differ for every scheme, identification and quantification of these sources and areas with higher sediment contributions should be the starting point in addressing problems of excessive sedimentation. Second, collaborating with farmers can help engineers and researchers to acquaint with the system and also to provide reasonable data within a short period of time. Third, reduced costs to clean irrigation canals should be included as a direct benefit of soil conservation plans, in addition to such plans' benefits for upland farmers.

Author Contributions: Conceptualization, Z.A.G.; methodology, Z.A.G.; data curation, Z.A.G.; formal analysis, Z.A.G.; writing — original draft preparation, Z.A.G.; review and editing, H.R., M.R., C.d.F. and M.A.; supervision, H.R., C.d.F. All authors have read and agreed to the published version of the manuscript.

Funding: This research was funded by Nuffic, Netherlands Initiative for Capacity building in Higher Education of the Netherlands government. It was conducted under the framework of the "Capacity Development of HEIs in Small-Scale Irrigation (and Micro Irrigation)" project (Nuffic/Niche/Eth/197).

Institutional Review Board Statement: Not applicable.

Informed Consent Statement: Not applicable. 
Data Availability Statement: Data was obtained from the Ethiopian National Meteorological Agency, Ministry of Water, Irrigation and Energy, the International Soil Reference and Information Center (ISRIC) and are available from the respective organizations.

Acknowledgments: The authors are very grateful to Nuffic, UNESCO-IHE, Delft and Wageningen University, Arba Minch University, Adama Science and Technology University, East Shoa and Arsi Zone offices and Woreda Irrigation Development Authority of the Oromia regional state, the Ethiopian National Meteorology Agency, and the Ministry of Agriculture and Natural Resources for their financial and material support to the study.

Conflicts of Interest: The authors declare no conflict of interest. The funders had no role in the design of the study; in the collection, analyses, or interpretation of data; in the writing of the manuscript, or in the decision to publish the results.

\section{Appendix A}

Table A1. Labour input and sediment output of the Arata-Chufa and Ketar irrigation scheme: adopted from Gurmu et al., 2019.

\begin{tabular}{|c|c|c|c|c|c|c|}
\hline A & B & $\mathrm{C}$ & D & E & $\mathbf{F}$ & G \\
\hline \multirow[t]{2}{*}{ Year } & $\begin{array}{l}\text { Farmers } \\
\text { Involved }\end{array}$ & $\begin{array}{c}\text { Working } \\
\text { Hours }\end{array}$ & Working Days & $\begin{array}{l}\text { Sediment } \\
\text { Removed }\end{array}$ & Total Input & Out Put \\
\hline & (Number) & (h/Day) & (Days) & $\left(\mathrm{m}^{3}\right)$ & (Days) & (m³/Day/Farmer) \\
\hline \multicolumn{7}{|c|}{ Arata-Chufa } \\
\hline 2016 & - & - & - & 194 & - & \\
\hline 2017 & 260 & 4.5 & 6 & 185 & 878 & 0.21 \\
\hline 2018 & 252 & 4.5 & 5 & 163 & 709 & 0.23 \\
\hline Average & 256 & 4.5 & 5.5 & 181 & 794 & 0.22 \\
\hline \multicolumn{7}{|c|}{ Ketar } \\
\hline 2016 & - & - & - & 2720 & - & - \\
\hline 2017 & 1680 & 5 & 3 & 2690 & 3150 & 0.85 \\
\hline 2018 & 1646 & 5 & 3 & 2522 & 3086 & 0.81 \\
\hline Average & 1663 & 5 & 3 & 264 & 3118 & 0.83 \\
\hline
\end{tabular}

Note that $8 \mathrm{~h}$ /day of daily working hours is used to estimate labor days and the values from columns A to F are recorded/measured data and columns $\mathrm{F}$ and $\mathrm{G}$ are calculated values.

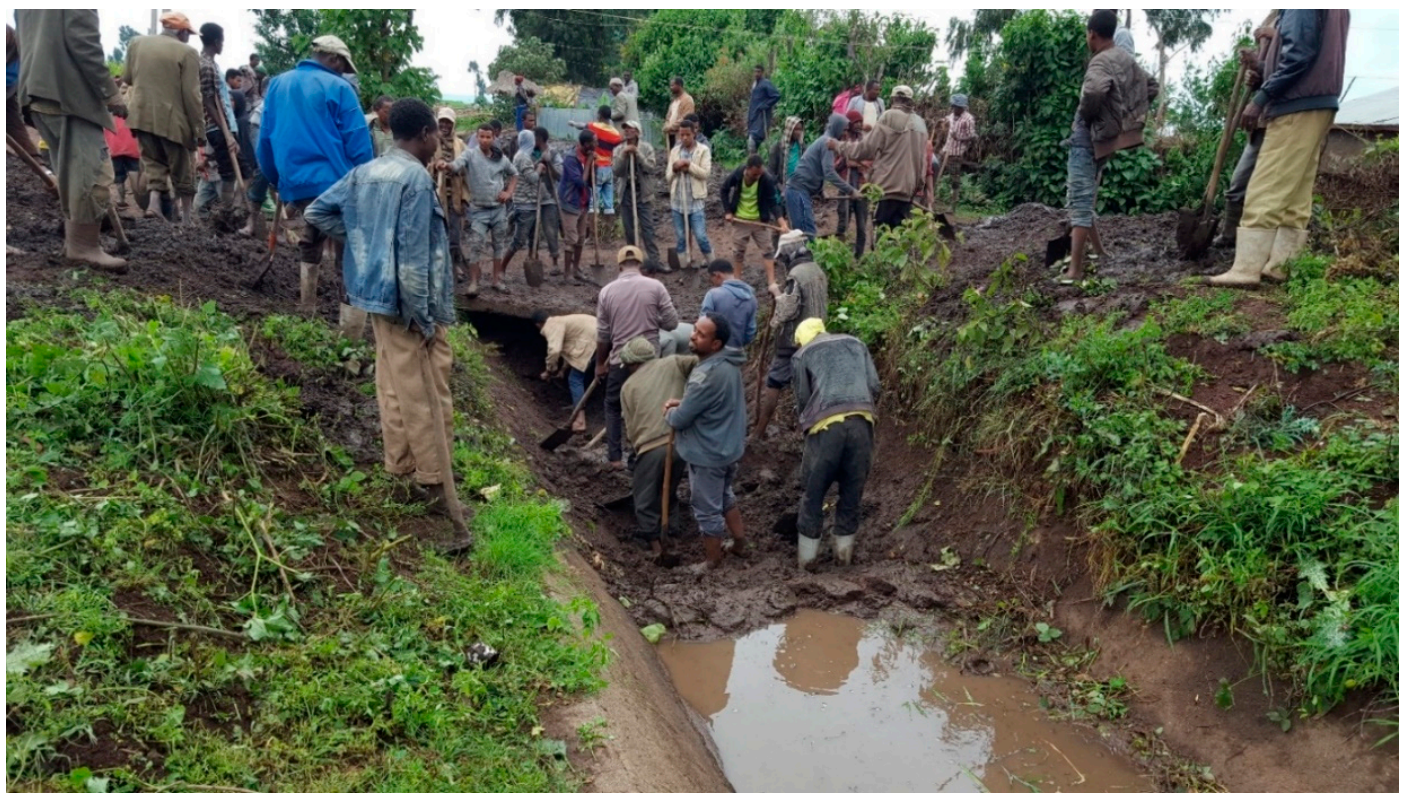

Figure A1. Farmers desilting the sediment from the main canal during the annual desilting campaign at the Ketar irrigation scheme. 


\section{References}

1. Haregeweyn, N.; Balana, B.B.; Melesse, B.; Tsunekawa, A.; Tsubo, M.; Meshesha, D.; Balana, B.B. Reservoir sedimentation and its mitigating strategies: A case study of Angereb reservoir (NW Ethiopia). J. Soil Sediments 2012, 12, 291-305. [CrossRef]

2. Moridi, A.; Yazdi, J. Sediment flushing of reservoirs under environmental considerations. Water Resour. Manag. 2017, 31, 1899-1914. [CrossRef]

3. Kondolf, G.M.; Gao, Y.; Annandale, G.W.; Morris, G.L.; Jiang, E.; Zhang, J.; Cao, Y.; Carling, P.; Fu, K.; Guo, Q.; et al. Sustainable sediment management in reservoirs and regulated rivers: Experiences from five continents. Earth's Future 2014, 2, 256-280. [CrossRef]

4. Aynekulu, E.; Atakliti, S.; Ejersa, A. Small-Scale Reservoir Sedimentation Rate Analysis for a Reliable Estimation of Irrigation Schemes Economic Lifetime: A Case Study of Adigudom Area Tigray, Northern Ethiopia; Faculty of Dryland Agriculture and Natural Resources, Mekelle University: Tigray, Ethiopia, 2009.

5. Mekonnen, M.M.; Keesstra, S.D.; Baartman, J.E.M.; Ritsema, C.J.; Melesse, A.M. Evaluating sediment storage dams: Structural off-site sediment trapping measures in Northwest Ethiopia. Cuad. Investig. Geogr. 2015, 41, 722. [CrossRef]

6. Moges, M.M.; Abay, D.; Engidayehu, H. Investigating reservoir sedimentation and its implications to watershed sediment yield: The case of two small dams in data-scarce upper Blue Nile Basin, Ethiopia. Lakes Reserv. Res. Manag. 2018, 23, 217-229. [CrossRef]

7. Sumi, T. Reservoir sedimentation management with bypass tunnels in Japan. In Proceedings of the of the Ninth International Symposium on River Sedimentation, Yichang, China, 18-21 October 2004; pp. 1036-1043.

8. Haregeweyn, N.; Poesen, J.; Nyssen, J.; De Wit, J.; Haile, M.; Govers, G.; Deckers, S. Reservoirs in Tigray (Northern Ethiopia): Characteristics and sediment deposition problems. Land Degrad Dev. 2006, 17, 211-230. [CrossRef]

9. Mekonen, A. Green Accounting Puts Price on Ethiopian Soil Erosion and Deforestation. Available online: http://efdinitiative. org/our-work/policy-interactions/green-accounting-puts-price-ethiopian-soil-erosion-and-deforestation (accessed on 21 February 2021).

10. Young, A. Land Resources: Now and for the Future; Cambridge University Press: Cambridge, UK, 1998.

11. Braimoh, A.K.; Vlek, P.L.G. Land Use and Soil Resources; Springer: Dordrecht, The Netherlands, 2008. [CrossRef]

12. Amede, T. Technical and institutional attributes constraining the performance of small-scale irrigation in Ethiopia. Water Resour. Rural Dev. 2015, 6, 78-91. [CrossRef]

13. Awulachew, S.; Ayana, M. Performance of irrigation: An assessment at different scales in Ethiopia. Exp. Agric. 2011, 47, 57-69. [CrossRef]

14. Gurmu, Z.A.; Ritzema, H.; de Fraiture, C.; Ayana, M. Sedimentation in small-scale irrigation schemes in Ethiopia: It sources and management. J. Soil Sediments 2021. submitted for publication.

15. Abera, A.; Verhoest, N.E.C.; Tilahun, S.A.; Alamirew, T.; Adgo, E.; Moges, M.M.; Nyssen, J. Performance of small-scale irrigation schemes in Lake Tana Basin of Ethiopia: Technical and socio-political attributes. Phys. Geogr. 2019, 40, 227-251. [CrossRef]

16. Gurmu, Z.A.; Ritzema, H.; de Fraiture, C.; Ayana, M. Stakeholder roles and perspectives on sedimentation management in small-scale irrigation schemes in Ethiopia. Sustainability 2019, 11, 6121. [CrossRef]

17. Theol, S.; Jagers, B.; Yangkhurung, J.R.; Suryadi, F.X.; de Fraiture, C. Effect of Gate Selection on the Non-Cohesive Sedimentation in Irrigation Schemes. Water 2020, 12, 2765. [CrossRef]

18. Ganasri, B.P.; Ramesh, H. Assessment of soil erosion by RUSLE model using remote sensing and GIS-A case study of Nethravathi Basin. Geosci. Front. 2016, 7, 953-961. [CrossRef]

19. Haregeweyn, N.; Tsunekawa, A.; Poesen, J.; Tsubo, M.; Meshesha, D.T.; Fenta, A.A.; Nyssen, J.; Adgo, E. Comprehensive assessment of soil erosion risk for better land use planning in River Basins: Case study of the Upper Blue Nile River. Sci. Total Environ. 2017, 574, 95-108. [CrossRef]

20. Kumar, T.; Jhariya, D.C.; Pandey, H.K. Comparative study of different models for soil erosion and sediment yield in Pairi watershed, Chhattisgarh, India. Geocarto Int. 2019, 1-22. [CrossRef]

21. Wischmeier, W.H.; Smith, D.D. Predicting Rainfall Erosion Losses: A Guide to Conservation Planning; U.S. Department of Agriculture: Bestville, MD, USA, 1978; Volume 537, p. 67.

22. Hurni, H. Erosion-productivity-conservation systems in Ethiopia. In Proceedings of the IV International Conference on Soil Conservation, Maracay, Venezuela, 3-9 November 1985; pp. 654-674.

23. Hurni, H. Soil Conservation Manual for Ethiopia: A Field Guide for Conservation Implementation; Ministry of Agriculture: Addis Ababa, Ethiopia, 1985.

24. Gelagay, H.S.; Minale, A.S. Soil loss estimation using GIS and remote sensing techniques: A case of Koga watershed, Northwestern Ethiopia. Int. Soil Water Conserv. 2016, 4, 126-136. [CrossRef]

25. Williams, J.R. Computer models of watershed hydrology. In The EPIC Model; Singh, V.P., Ed.; Water Resources Publications: Highlands Ranch, CO, USA, 1995.

26. Moore, I.D.; Wilson, J.P. Length-slope factors for the revised universal soil loss equation: Simplified method of estimation. J. Soil Water Conserv. 1992, 47, 423-428. 
27. Schmidt, S.; Tresch, S.; Meusburger, K. Modification of the RUSLE slope length and steepness factor (LS-factor) based on rainfall experiments at steep alpine grasslands. MethodsX 2019, 6, 219-229. [CrossRef]

28. Qin, W.; Guo, Q.; Cao, W.; Yin, Z.; Yan, Q.; Shan, Z.; Zheng, F. A new RUSLE slope length factor and its application to soil erosion assessment in a Loess Plateau watershed. Soil Till Res. 2018, 182, 10-24. [CrossRef]

29. Hickey, R.; Smith, A.; Jankowski, P. Slope length calculations from a DEM within ARC/INFO grid. Comput. Environ. Urban. Syst 1994, 18, 365-380. [CrossRef]

30. Wang, M.; Baartman, J.E.M.; Zhang, H.; Yang, Q.; Li, S.; Yang, J.; Cai, C.; Wang, M.; Ritsema, C.J.; Geissen, V. An integrated method for calculating DEM-based RUSLE LS. Earth Sci. Inform. 2018, 11, 579-590. [CrossRef]

31. Desmet, P.J.J.; Govers, G. A GIS procedure for automatically calculating the USLE LS factor on topographically complex landscape units. J. Soil Water Conserv. 1996, 51, 427.

32. Almagro, A.; Thomé, T.C.; Colman, C.B.; Pereira, R.B.; Marcato Junior, J.; Rodrigues, D.B.B.; Oliveira, P.T.S. Improving cover and management factor (C-factor) estimation using remote sensing approaches for tropical regions. Int. Soil Water Conserv. Res. 2019, 7, 325-334. [CrossRef]

33. Panagos, P.; Borrelli, P.; Meusburger, K.; van der Zanden, E.H.; Poesen, J.; Alewell, C. Modelling the effect of support practices (P-factor) on the reduction of soil erosion by water at European scale. Environ. Sci. Policy 2015, 51, 23-34. [CrossRef]

34. Taye, G.; Vanmaercke, M.; Poesen, J.; Wesemael, B.V.; Tesfaye, S.; Teka, D.; Nyssen, J.; Deckers, J.; Haregeweyn, N. Determining RUSLE P- and C-factors for stone bunds and trenches in rangeland and cropland, North Ethiopia. Land Degrad Dev. 2018, 29, 812-824. [CrossRef]

35. Nyssen, J.; Clymans, W.; Poesen, J.; Vandecasteele, I.; De Baets, S.; Haregeweyn, N.; Naudts, J.; Hadera, A.; Moeyersons, J.; Haile, M.; et al. How soil conservation affects the catchment sediment budget-A comprehensive study in the north Ethiopian highlands. Earth Surf. Proc. Landf. 2009, 34, 1216-1233. [CrossRef]

36. Shin, G.J. The Analysis of Soil Erosion Analysis in Watershed Using GIS. Ph.D. Thesis, Gang-won National, Chuncheon, Korea, 1999.

37. Haregeweyn, N.; Poesen, J.; Nyssen, J.; Govers, G.; Verstraeten, G.; de Vente, J.; Deckers, J.; Moeyersons, J.; Haile, M. Sediment yield variability in Northern Ethiopia: A quantitative analysis of its controlling factors. CATENA 2008, 75, 65-76. [CrossRef]

38. Williams, J.R.; Berndt, H.D. Sediment yield computed with universal equation. J. Hydrau. Div. 1972, 98, 2087-2098. [CrossRef]

39. Jain, S.K.; Singh, P.; Saraf, A.K.; Seth, S.M. Estimation of sediment yield for a rain, snow and glacier fed river in the Western Himalayan Region. Water Resour. Manag. 2003, 17, 377-393. [CrossRef]

40. Bhattarai, R.; Dutta, D. Estimation of soil erosion and sediment yield using GIS at catchment scale. Water Resour. Manag. 2006, 21, 1635-1647. [CrossRef]

41. Onyando, J.O.; Kisoyan, P.; Chemelil, M.C. Estimation of potential soil erosion for river Perkerra catchment in Kenya. Water Resour. Manag. 2005, 19, 133-143. [CrossRef]

42. Wang, G.; Gertner, G.; Singh, V.; Shinkareva, S.; Parysow, P.; Anderson, A. Spatial and temporal prediction and uncertainty of soil loss using the revised universal soil loss equation: A case study of the rainfall-runoff erosivity R factor. Ecol. Model. 2002, 153, 143-155. [CrossRef]

43. Biesemans, J.; Van Meirvenne, M.; Gabriels, D. Extending and RUSLE with the Monte Carlo error propagation technique to predict long-term average off-site sediment accumulation. J. Soil Water Conserv. 2000, 55, 35-42.

44. Falk, M.G.; Denham, R.J.; Mengersen, K.L. Estimating uncertainty in the revised universal soil loss equation via Bayesian melding. J. Agric. Biol. Environ. Stat. 2010, 15, 20-37. [CrossRef]

45. Herr, A.; Kuhnert, P.M. Assessment of uncertainty in Great Barrier Reef catchment models. Water Sci. Technol. 2007, 56, 181-188. [CrossRef] [PubMed]

46. Haregeweyn, N.; Tsunekawa, A.; Nyssen, J.; Poesen, J.; Tsubo, M.; Tsegaye Meshesha, D.; Schütt, B.; Adgo, E.; Tegegne, F. Soil erosion and conservation in Ethiopia. Prog. Phys. Geogr. 2015, 39, 750-774. [CrossRef]

47. Belayneh, M.; Yirgu, T.; Tsegaye, D. Potential soil erosion estimation and area prioritization for better conservation planning in Gumara watershed using RUSLE and GIS techniques'. Environ. Syst. Res. 2019, 8. [CrossRef]

48. Selassie, Y.G.; Belay, Y. Costs of nutrient losses in priceless soils eroded from the highlands of Northwestern Ethiopia. J. Agric. Sci. 2013, 5, 1916-9760. [CrossRef]

49. Amsalu, T.; Mengaw, A. GIS based soil soss estimation using RUSLE model: The case of Jabi Tehinan Woreda, ANRS, Ethiopia. Nat. Resour. J. 2014, 5, 616-626. [CrossRef]

50. Yesuph, A.Y.; Dagnew, A.B. Soil erosion mapping and severity analysis based on RUSLE model and local perception in the Beshillo Catchment of the Blue Nile Basin, Ethiopia. Environ. Syst. Res. 2019, 8. [CrossRef]

51. Sonneveld, B.G.J.S.; Keyzer, M.A.; Stroosnijder, L. Evaluating quantitative and qualitative models: An application for nationwide water erosion assessment in Ethiopia. Environ. Modell. Softw. 2011, 26, 1161-1170. [CrossRef]

52. Kebede, W.; Habitamu, T.; Efrem, G.; Fantaw, Y. Soil erosion risk assessment in the Chaleleka wetland watershed, Central Rift Valley of Ethiopia. Environ. Syst. Res. 2015, 4, 5. [CrossRef]

53. Hui, L.; Xiaoling, C.; Lim, K.J.; Xiaobin, C.; Sagong, M. Assessment of soil erosion and sediment yield in Liao watershed, Jiangxi Province, China, using USLE, GIS, and RS. J. Earth Sci. China 2010, 21, 941-953. [CrossRef] 
54. Mahala, A. Soil erosion estimation using RUSLE and GIS techniques—a study of a plateau fringe region of tropical environment. Arab. J. Geosci. 2018, 11, 1-18. [CrossRef]

55. FAO. Ethiopian Highlands Reclamation Study; Food and Agriculture Organization of the United Nations: Rome, Italy, 1984.

56. Hurni, H. Ethiopian Highlands Reclamation Study, Soil Formation Rates in Ethiopia; Food and Agriculture Organization of the United Nations: Addis Ababa, Ethiopia, 1983.

57. Kouli, M.; Soupios, P.; Vallianatos, F. Soil erosion prediction using the revised universal soil loss equation (RUSLE) in a GIS framework, Chania, Northwestern Crete, Greece. Environ. Geol. 2009, 57, 483-497. [CrossRef] 